\title{
A Comprehensive Review on Thermal Coconversion of Biomass, Sludge, Coal, and Their Blends Using Thermogravimetric Analysis
}

\author{
Zeeshan Hameed, ${ }^{1}$ Salman Raza Naqvi, ${ }^{1}$ Muhammad Naqvi iD, ${ }^{2}$ Imtiaz Ali, ${ }^{3}$ \\ Syed Ali Ammar Taqvi, ${ }^{4}$ Ningbo Gao $\mathbb{D}^{5},{ }^{5}$ Syed Azfar Hussain, ${ }^{6}$ and Sadiq Hussain ${ }^{7}$ \\ ${ }^{1}$ School of Chemical \& Materials Engineering, National University of Sciences \& Technology, Islamabad, Pakistan \\ ${ }^{2}$ Department of Engineering and Chemical Sciences, Karlstad University, Karlstad, Sweden \\ ${ }^{3}$ Department of Chemical and Materials Engineering, King Abdulaziz University, Rabigh, Saudi Arabia \\ ${ }^{4}$ Department of Chemical Engineering, NED University of Engineering \& Technology, Karachi, Pakistan \\ ${ }^{5}$ School of Energy and Power Engineering, Xi'an Jiaotong University, Xi'an 710049, China \\ ${ }^{6}$ Department of Chemical Engineering, Ecole Polytechnique de Montréal, Montréal, Canada \\ ${ }^{7}$ Department of Chemical Engineering, NFC-Institute of Engineering \& Technology, Khanewal Road, Multan, Pakistan
}

Correspondence should be addressed to Muhammad Naqvi; raza.naqvi@kau.se

Received 28 February 2020; Revised 16 May 2020; Accepted 22 June 2020; Published 4 August 2020

Academic Editor: Hassan Arida

Copyright (c) 2020 Zeeshan Hameed et al. This is an open access article distributed under the Creative Commons Attribution License, which permits unrestricted use, distribution, and reproduction in any medium, provided the original work is properly cited.

\begin{abstract}
Lignocellulosic biomass is a vital resource for providing clean future energy with a sustainable environment. Besides lignocellulosic residues, nonlignocellulosic residues such as sewage sludge from industrial and municipal wastes are gained much attention due to its large quantities and ability to produce cheap and clean energy to potentially replace fossil fuels. These cheap and abundantly resources can reduce global warming owing to their less polluting nature. The low-quality biomass and high ash content of sewage sludge-based thermal conversion processes face several disadvantages towards its commercialization. Therefore, it is necessary to utilize these residues in combination with coal for improvement in energy conversion processes. As per author information, no concrete study is available to discuss the synergy and decomposition mechanism of residues blending. The objective of this study is to present the state-of-the-art review based on the thermal coconversion of biomass/sewage sludge, coal/ biomass, and coal/sewage sludge blends through thermogravimetric analysis (TGA) to explore the synergistic effects of the composition, thermal conversion, and blending for bioenergy production. This paper will also contribute to detailing the operating conditions (heating rate, temperature, and residence time) of copyrolysis and cocombustion processes, properties, and chemical composition that may affect these processes and will provide a basis to improve the yield of biofuels from biomass/ sewage sludge, coal/sewage sludge, and coal/biomass blends in thermal coconversion through thermogravimetric technique. Furthermore, the influencing factors and the possible decomposition mechanism are elaborated and discussed in detail. This study will provide recent development and future prospects for cothermal conversion of biomass, sewage, coal, and their blends.
\end{abstract}

\section{Introduction}

Fossil fuels have been extensively used for the last two centuries to meet the energy demand of the growing population for global development [1-3]. The increase in the environmental and sustainability summons due to the greenhouse emissions that are related to fossil fuel usage and the unceremonious distribution of fossil fuel resources has increased the global energy $[4,5]$. It is the need of the time to introduce an alternate energy approach to meet current and future energy demands [6]. The replacement of conventional fossil fuels with sewage sludge, coal, and lignocellulosic biomass fuels as renewable energy resources is considered promising as these have already contributed to around $10 \%$ of the global energy supply [7-12]. Soncini et al. stated that from the past thirty years, lignocellulosic biomass was a focal 
point of research for renewable energy because $56 \%$ of energy is provided by biomass, $26 \%$ by solar, $11 \%$ by wind power, $5 \%$ by geothermal energy, and $2 \%$ by hydropower [13]. In the future, utilization of renewable sources and biofuels will increase from 2 to $27 \%$ [14]. The abundance of biomass and sewage sludge coupled with lower environmental concern and technical ease is the main reason for intensive research and utilization of these sources as feedstocks [15].

Coal is the largest source of energy in the United States (fulfilling to about $42 \%$ of net energy demand) [16]. Global coal demand dropped during 2014-2016 despite the economic growth during these two years. The growth in the energy demand in China, the US, and Europe has been met partly by renewables and natural gas switch in power generation from coal. However, coal demand grew in India and South East Asia Region due to the increased power demand for their social development and growing economies. Still, in the 21st century, coal is a major source of world energy due to lower cost and a higher energy density [17]. It is expected that coal will contribute to future energy demands in many fast-developing countries, such as China and India [18]. The conversion of biomass to fuels and chemicals by thermal conversion has a substantial value in the petrochemical industry (Figure 1). The major downside of coal is that it is responsible for the emission of ecologically damaging compounds such as sulfur $(\mathrm{S})$, nitrogen $(\mathrm{N})$, and heavy metals, so its utilization with biomass and sewage sludge can mitigate the impact [21].

Lignocellulosic biomass, a clean and alternative energy source, has been the point of focus for its abundance and the lower tendency of greenhouse gas emissions [22]. $\mathrm{CO}_{2}$ exhausted from the burning of biomass is absorbed through photosynthesis, thereby controlling global warming $[23,24]$. Sewage sludge is another important energy source to produce biofuels through thermochemical conversion, which also solves the disposal problem of waste sludge. The dried sewage sludge is reasonably rich in volatile matters and high in calorific value [25]. Cellulose, hemicellulose, lignin, and extractives are the main constituents of lignocellulosic biomass. Lignocellulosic biomass can be crudely categorized as woody, nonwoody, and wastes. These can be converted into bio-oils, gases, and chemicals through different thermochemical processes such as pyrolysis, gasification, liquefaction, and high-pressure supercritical extraction [26, 27]. Lignocellulosic biomass is considered as the largest sustainable energy source and approximately 220 billion tons of dry biomass is produced annually. It is also called the sole source of obtaining energy because it provides around $14 \%$ of the world's energy supply. According to the UN Food and Agriculture Organization, the world biomass production has increased from 19 million tons to 25 million tons in between 2012 and 2017 [28]. The coconversion of lignocellulosic biomass and sludge by using copyrolysis process can improve the quality of bio-oils and other gaseous products. The use of copyrolysis processes is gaining attention due to its simple and efficient operation to produce liquid [29]. Copyrolysis of lignocellulosic biomass and coal blends can offer several advantages such as reduction in
$\mathrm{CO}_{2}, \mathrm{SOx}$, and NOx emissions and improve economy and efficiency [30]. A thermogravimetric analyser (TGA) can study the behavior and characteristics of coconversion through copyrolysis. TGA is an important tool to study thermal degradation behavior and synergic effect of many copyrolysis samples [31, 32]. TGA measures the percentage of mass loss of a sample with respect to temperature and time from these data; thermal decomposition behavior during pyrolysis is examined [33]. Moreover, kinetics of degradation of organic material during the pyrolysis process can also be investigated. Thermal degradation is an important factor in designing pyrolysis and copyrolysis processes. TGA is also useful in studying the synergy of different feedstock such as coal, lignocellulosic biomass, and sludge. The synergetic effects depend on the different types of feedstock mix, the intensity of sample contact, type of reactor, experimental conditions, and characteristics of the sample [34]. The effect of mixing ratio and temperature on the product distribution can also be studied by TGA. The most important advantage of thermal coconversion of coal, lignocellulosic biomass, and sewage sludge blends is the reduction in the harmful emissions. Thermal coconversion of biomass and sludge with coal is a relatively profound, cost-effective, and efficient process [35]. Thermal conversion of lignocellulosic biomass can reduce the landfill methane emission and coconversion can reduce the $\mathrm{N}_{2} \mathrm{O}$ emission as compared to the conversion of coal alone [36]. Thermal coconversion of coal and lignocellulosic biomass offers a better way to utilize coal and wastes/biomass in an inexpensive, harmless, and environmentally acceptable manner [37].

Previously published work on the thermal conversion of the different types of lignocellulosic biomass, sewage sludge, and coal is summarized in many review articles (Figure 2). Some review articles have focused on the advancement of conversion techniques to improve the oil quality (Figure 3). However, blending ratio is an important factor in thermal coconversion biomass and sludge/coal, and to the best of authors' knowledge, there is no comprehensive review on the thermal coconversion of different blends using TGA. The compiled data and related discussions in this review will be beneficial in designing and developing efficient cothermal processes.

Thermal coconversion is getting much attention recently from the researcher due to its economic as well as environmental benefits. Especially during the past ten years, an exponential increase has been seen in the published literature at Web of Science related to thermal coconversion of coal/sludge or coal/biomass.

The work has been mostly published by the authors from the developing and developed nations. China is by far leading the rest of the world. Compared to sludge, the copyrolysis of coal/biomass is found in more instances. Most of the related literature appeared in Bioresource Technology, Energy and Fuels, Fuel, and Journal of Analytical and Applied Pyrolysis (Figure 4). From 2010 onwards, a sharp increase in the number of published papers is quite evident.

The aim of this paper is to comprehensively review the thermal coconversion of the different types of lignocellulosic biomass, sewage sludge, and coal to reveal the synergistic 


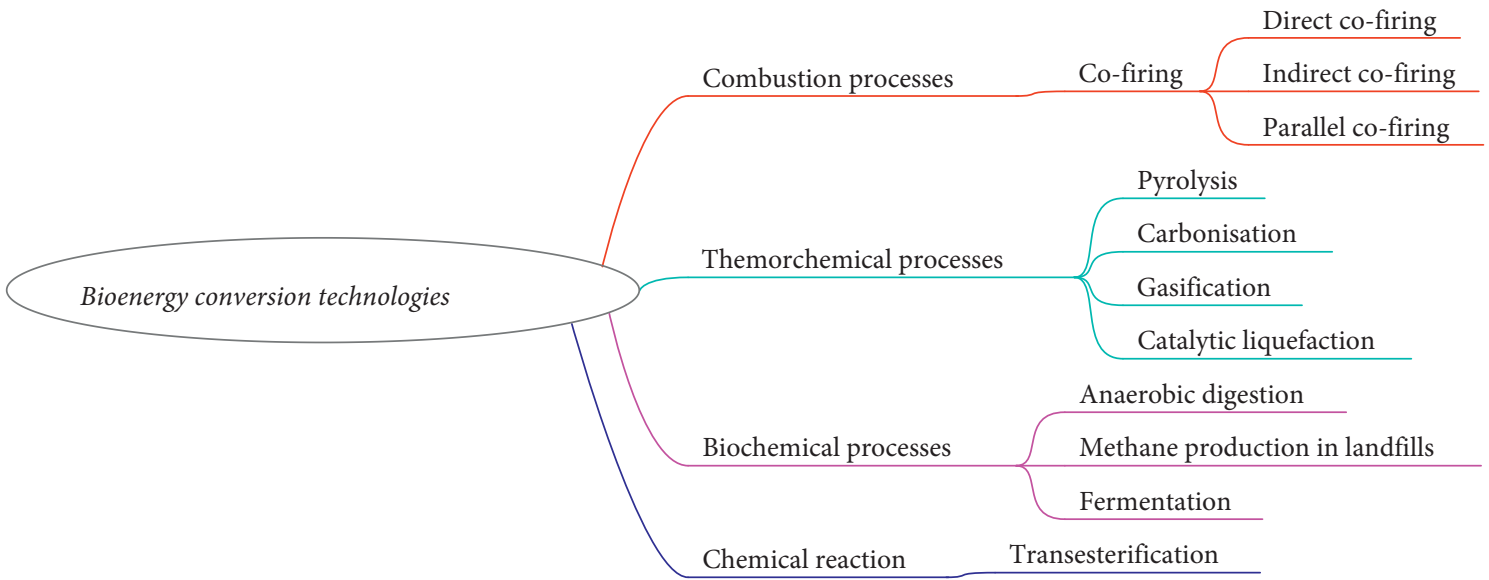

Figure 1: Biomass conversion processes [19, 20].

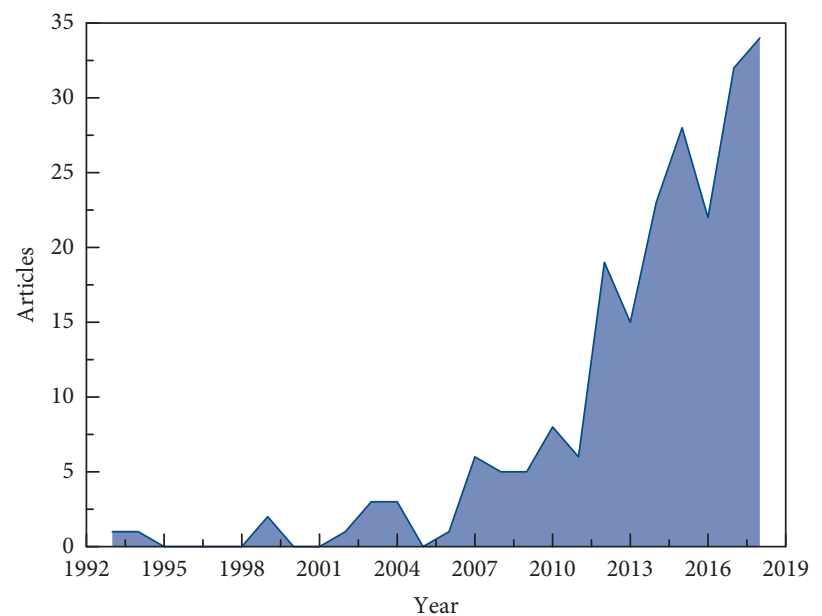

Figure 2: Annual scientific publication on the cothermal conversion of coal/sludge or coal/biomass appeared in the Web of Science database.

effect of their composition, conversion processes, and blending impact. Previously, there are no concrete and unique studies coupled with thermal coconversion (pyrolysis or combustion) of biomass, sludge, coal, and their blends and discussed their challenges. In addition, some comprehensive discussion is provided emphasizing the behavior of lignocellulosic biomass and blending ratio with coal and sewage sludge focusing on the relevant properties and technical issues that may influence the yield of bio-oils during thermal coconversion. In result, the effect of the properties and chemical composition of blending mixtures of sewage sludge, coal, and lignocellulosic biomass blends on the behavior of these processes will provide pinpoints to increase the efficiency and yield of biofuels obtained from biomass/sewage sludge, coal/sewage sludge, and coal/biomass blends by improving the operating conditions of TGA technique.

\section{Feedstock and Thermal Coconversion}

The selection of feedstock mainly depends on two factors: availability and the property of the material. The feedstock is divided into three main categories. One is lignocellulosic biomass other is coal, and the third is municipal waste.

2.1. Lignocellulosic Biomass. The most abundant feedstock is lignocellulosic biomass. Any organic material that can be burned and used as a fuel is called lignocellulosic biomass. Lignocellulosic biomass is the most convenient energy asset that can be used to obtain different liquid fuels and bio-oils. All types of lignocellulosic biomass are classified into primary, secondary, and tertiary biomass based on their resource. Primary biomass can be formed directly by using solar energy and is grown from the land such as woody crops, oilseeds, rice husk, corn comb, rice straw, and bark from trees [38]. An energy research indicated that biomass has the capability to fulfil $10 \%$ of the energy supply globally [39]. Secondary biomass can be generated from chemical, physical, and biological processing of primary biomass resources. The bulging substitute as a raw material for bio-oil production for industrial corporations is usually plantderived biomass, such as corn, sweet sorghum, sugarcane 


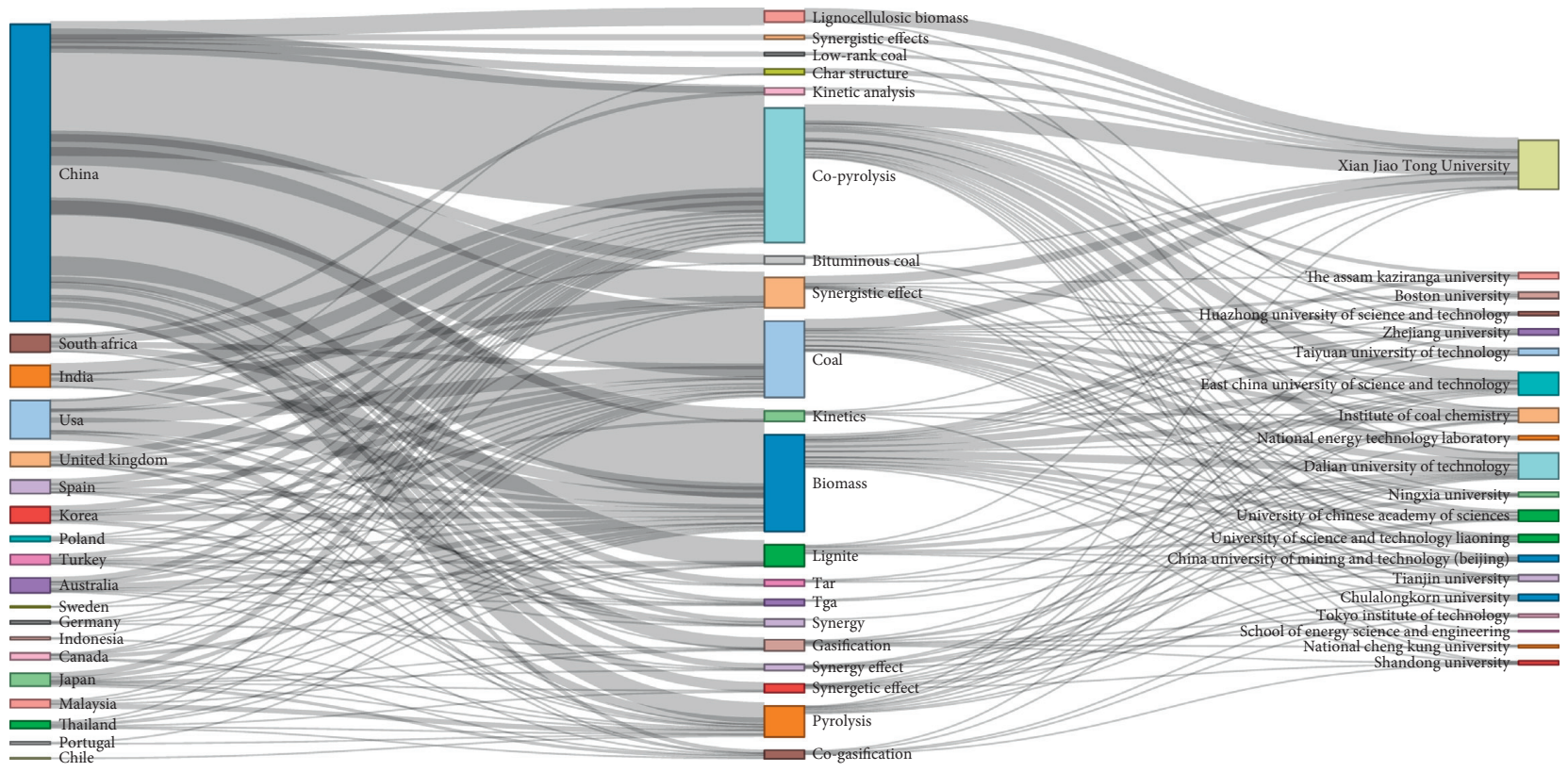

Figure 3: Sankey three-field plot of countries/keywords/affiliations.

bagasse, wheat, and crop residue, and the feedstock prices are very practical, for example, $7.40 \mathrm{US} \$ /$ ton in which transportation cost is also included. Accordingly, commercialization of this second-generation biomass turned is being considered as very auspicious and valuable [40]. Tertiary biomass consists of animal fats, used vegetable oil, packaging wastes, and construction wastes. Hossain et al. indicated that microalgae wedged the awareness of presence as third-generation source of biofuel, raw material, nutriment, and collections of extremely treasured products in medicinal and agricultural industries [41]. She also suggested microalgae fuel could be applied for electricity generation by using static diesel engines. They all are composed of cellulose, hemicellulose, lignin, and extractives. Lignocellulosic biomass has the tendency to be transformed into bio-oils, gases, and chemicals [42, 43].

2.2. Coal. The other feedstock is coal, which is the second largest source used for energy and can be classified into bituminous, subbituminous, and lignite according to property and origin. Coal is a natural and abundant source to be used. The United States has approximately 260 billion short tons of recoverable reserves, that is, $27 \%$ of total reserves around the world. There are many studies which prove the potential of different types of coal in the usage of thermochemical conversion process under different operating conditions.

2.3. Sewage Sludge. The next important feedstock is sewage sludge, which is obtained from the municipal and industrial wastewater treatment plants. Sludge is collected as lumps, so it is necessary to reduce particle size and remove the excess moisture content $(<10 \%)$ to upgrade the quality of the feedstock. To improve the quality of the products, the feedstocks of different properties are mixed in desired blending ratios. Sewage sludge can provide energy and fuel by thermochemical conversion, so this is considered as the most promising alternate technology to reduce the amount of waste and harmful environmental impact. The amount of sewage sludge production is largely depending upon the level and method of treatment applied to wastewater, population growth, and volume of wastewater stream [44]. As indicated by Fytili et al., dried sewage has unpredictable substance of $30-88 \%$ and calorific esteem normally $11-25.5 \mathrm{MJ} / \mathrm{kg}$ [45]. The utilization of sewage sludge as sustainable power source assets is taken as a healthier choice since this source can give around $10 \%$ of worldwide vitality stock [30].

2.4. Thermal Coconversion. The conversion of individual coal through thermochemical conversation has environmental challenges in terms of harmful emission which can be minimized by using thermal coconversion of different raw materials, biomass, coal, and sewage sludge bends in different ratios [46]. The thermal coconversion depends upon how feedstock interacts under a specific condition with the specified ratio. Zhang et al. studied the synergy effect of lignite coal and biomass by grinding and sieving at a particle size range of $0.3-0.45 \mathrm{~mm}$ with $1: 1$ and dried it in an oven at $105^{\circ} \mathrm{C}$ for $24 \mathrm{~h}$ to improve the yield of the products [47]. Biomass and sewage sludge fuels usually contain a lower amount of fixed carbon and a higher percentage of volatile matter as compared to coal. Usually, thermal coconversion of coal and biomass or sewage sludge produces less carbon-containing compounds such as $\mathrm{CO}_{2}$, $\mathrm{CO}, \mathrm{CH}_{4}$, and other light hydrocarbons as compared to the conversion of coal alone [48, 49]. Increasing biomass content in the blend can increase carbon-containing compounds like $\mathrm{CO}_{2}, \mathrm{CO}$, and light hydrocarbon gases while hydrogen content decreases. Kumabe et al. used 


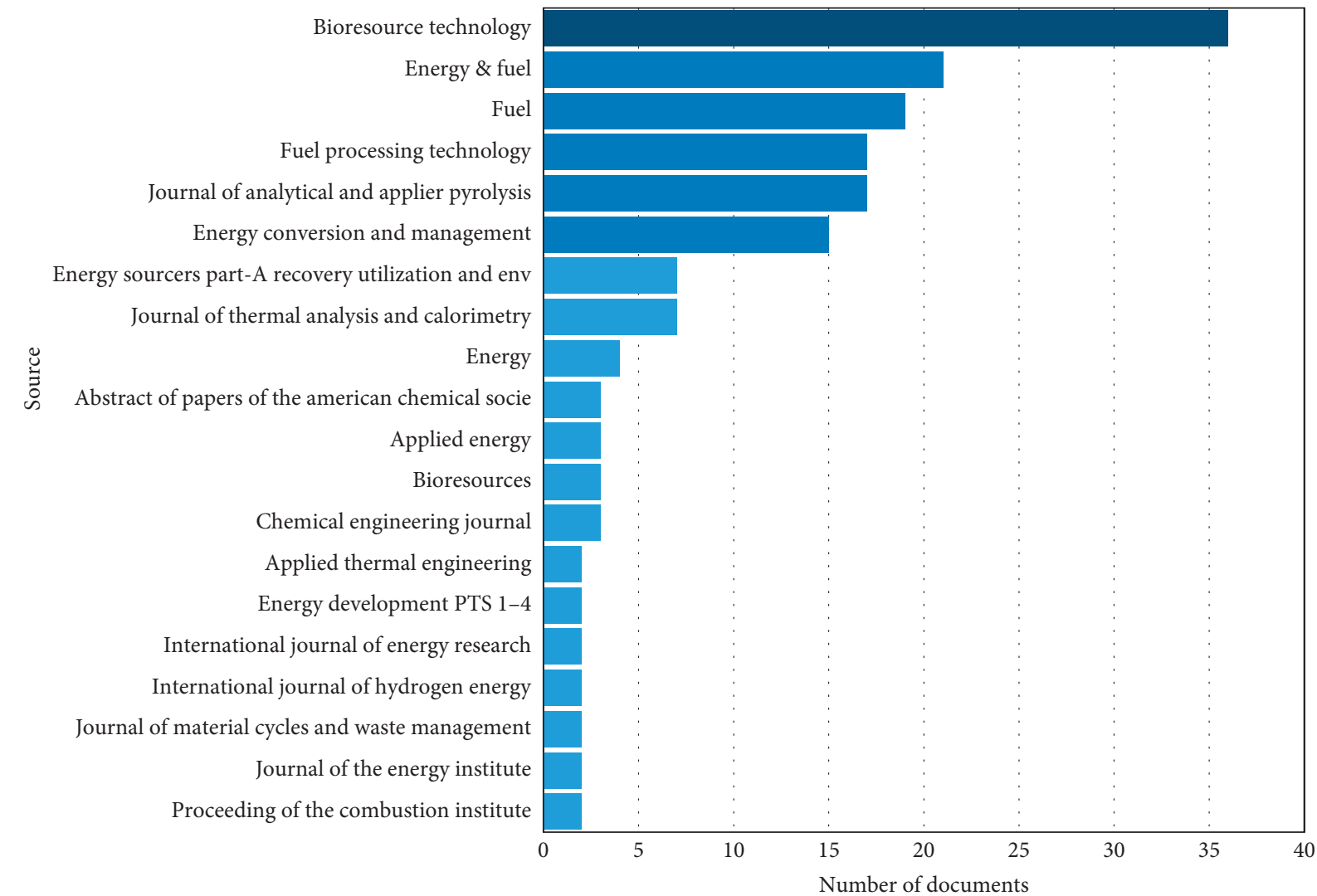

(a)

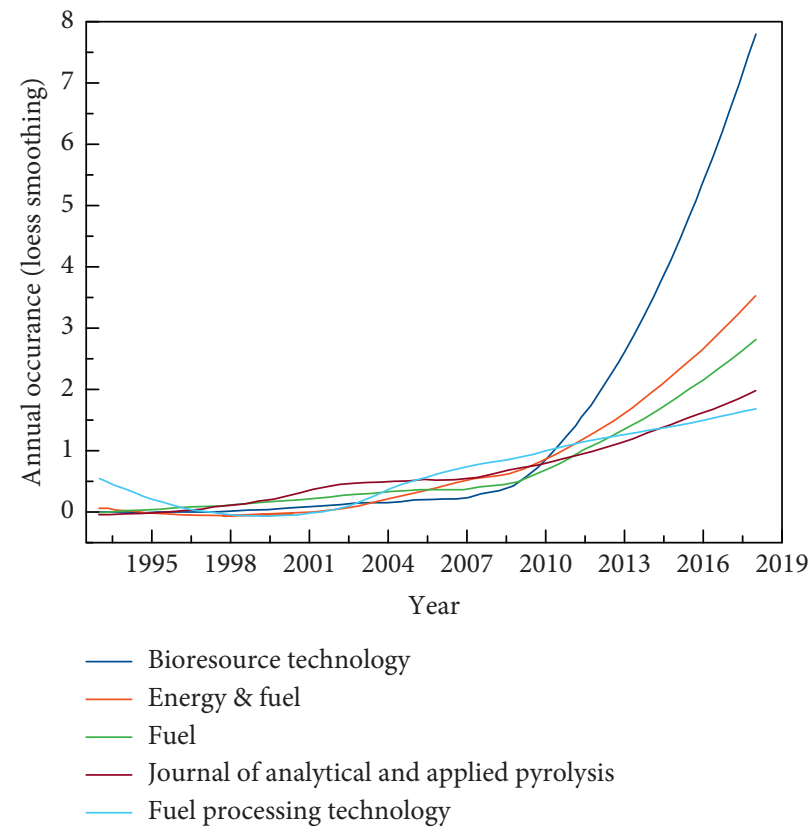

(b)

Figure 4: (a) Most relevant sources and (b) source growth rate. 
biomass with the higher hydrogen content to increase the proportion of the hydrogen in the product, but the contrary resulted in the product [50].

\section{Factors for Synergistic Effects on Thermal Coconversion}

3.1. Ultimate, Proximate, and Chemical Composition Analysis of Coal. Coal is the combustible material containing $50 \%$ by weight of carbon. It is a carbonaceous material with some percentage of hydrogen, oxygen, nitrogen, sulfur, and ash. Based on the fractions of hydrogen, oxygen, and carbon present in the sample, coal is ranked into four main categories such as bituminous coal, lignite, anthracite, and subbituminous coal [51]. Coal is usually dried at $105^{\circ} \mathrm{C}$ for $24 \mathrm{~h}$ in a muffle furnace or electric furnace to improve the high heating value (HHV). The raw hydrothermally treated moisture-free coal has some oxygenated functional group such as carboxyl, phenolic, hydroxyl, and all acidic groups. Table 1 shows the elemental composition, proximate analysis, and calorific value of the different coals. The ultimate analysis shows that coals contain higher carbon (60-90\%). The proximate analysis shows volatiles between $38 \%$ and $40 \%$ which is less than that present in sewage sludge and bagasse. The calorific value of coal not only depends on the moisture, ash, and oxygen contents, but it also varies with the drying process. The raw coal has a high HHV than residual coal, biomass, and sewage sludge. It has ranged from 8 to $38 \mathrm{MJ} / \mathrm{kg}$. Ash is the leftover residue after combustion at $900^{\circ} \mathrm{C}$. The elemental analysis of char obtained from a sample of coal showed trace amounts of $\mathrm{Li}, \mathrm{B}, \mathrm{Na}, \mathrm{Mg}, \mathrm{Al}, \mathrm{P}, \mathrm{K}, \mathrm{Ca}, \mathrm{Fe}$, and $\mathrm{Ba}$ [62]. Bhatt et al. reported the order of relative elemental abundance in coal as $\mathrm{Si}>\mathrm{Al}>\mathrm{Fe}>\mathrm{Ca}>\mathrm{Mg}>\mathrm{K}>\mathrm{Na}>\mathrm{Sr}>\mathrm{V}$ $>\mathrm{Zn}>\mathrm{Mn}>\mathrm{Cr}>\mathrm{Cu}>\mathrm{Pb}>\mathrm{Ni}>\mathrm{Co}>\mathrm{As}>\mathrm{Cd}$ [63]. According to the literature review, to obtain the maximum yield of liquid fuel through efficient pyrolysis operation, it is important to understand the properties, chemical composition, and behavior of different samples of coal. Bituminous coal has been used more often as it contains a higher amount of volatile matter, indicating its higher hydrocarbon potential. Depending on the region from where the coal was extracted, the amount of sulfur may vary between $1 \%$ and $4 \%$. Sulfur is an undesirable constituent of coal; it requires a pretreatment step to eliminate to avoid $\mathrm{SO}_{\mathrm{x}}$ formation during combustion.

3.2. Ultimate, Proximate, and Chemical Composition Analysis of Lignocellulosic Biomass. Any organic material that can be burned and used as a fuel is called lignocellulosic biomass. It is the most convenient energy resource that can obtain different liquid fuels and bio-oils. Lignocellulosic biomass is a nonfossil and complex biogenic solid composed of many organic and inorganic constituents that originate from natural and technical resources. Natural resources are obtained from land- and water-based vegetation or generated by animal and human food digestion. Technical resources are obtained from the processing of the above natural resources [64]. Some of which are trees, shrubs, bamboos, grass, and plant leaves and waste such as food, rubbish, and industrial and municipal waste. Agriculture and forest residues are also called lignocellulosic biomass because they are composed of cellulose, hemicellulose, and lignin. Some lignocellulosic biomass may contain extractives up to $10 \%$ [65]. Lignocellulosic biomass shows high reactivity during conversion as they contain lower ash, carbon, sulfur, and nitrogen and usually contain a higher amount of volatile matters, hydrogen, oxygen, phosphorous, calcium, and magnesium. Ash obtained from lignocellulosic biomass can capture hazardous material. Using biomass in copyrolysis has many benefits, as these are widely available cheapest sustainable energy resource and neutralize $\mathrm{CO}_{2}$ in the atmosphere [66]. The chemical composition of lignocellulosic biomass affects thermal copyrolysis behavior. Lignocellulosic biomass containing a higher amount of hemicellulose and cellulose favors a high conversion rate during pyrolysis. The hemicellulose and cellulose degrade at a lower temperature range of $220-400^{\circ} \mathrm{C}$ while lignin degrades at a higher temperature of $500-900^{\circ} \mathrm{C}[67,68]$. The study of lignocellulosic constituents is relevant in copyrolysis as various constituents behave differently when subjected to thermal degradation. According to Naqvi and Naqvi, lignocellulosic biomass contains $35-50 \mathrm{wt} . \%$ cellulose, 20-40 wt.\% hemicellulose, 20-27 wt.\% lignin, and 1-10 wt.\% extractives [26]. Properties differ among the biomass; their mixture or blends can be used to increase or reduce the required content at a certain level. Table 2 summarizes the proximate, ultimate, and chemical composition of different biomass samples. It can be observed that bagasse contains more volatiles than rice husk, showing that bagasse has higher thermal conversion ability than rice husk. Yu et al. find out that by increasing the pyrolysis temperature from $350-600^{\circ} \mathrm{C}$, higher heating value (HHV) and volatile matter content of char were also increased [74]. Rice husk and corn stalk released $\mathrm{CO}_{2}, \mathrm{CO}, \mathrm{CH}_{4}, \mathrm{H}_{2}$, and other light hydrocarbons after thermal conversion. Anil et al. investigated the physiochemical properties of various agricultural residues (cotton stalk, rice husk, rice straw, and baggase) in copyrolysis process [72]. It was observed that biomass has a higher percentage of volatile matter than that of coals and has a higher percentage of hemicellulose $47 \%$ as compared to cellulose and lignin. Table 3 depicts the elemental and chemical composition of products obtained from coal, lignocellulosic biomass, sludge, and their blends.

3.3. Ultimate, Proximate, and Chemical Composition Analysis of Sewage Sludge. The major source of sewage sludge is municipal wastewater treatment plants. Sewage sludge is a complex mixture of organic and inorganic substances [86]. The organic constituents are mainly proteins, peptides, lipids, polysaccharides, and plant macromolecules with phenolic structures or aliphatic structures along with organic micropollutants such as polycyclic aromatic hydrocarbons. The inorganic materials come from soil and polymer waste [87]. Samolada and Zabaniotou find out that sewage sludge also contains some precarious materials such as heavy metals, organic pollutants, and pathogens [88]. In most of the studies, the sewage sludge was dried at a certain temperature $\left(<110^{\circ} \mathrm{C}\right)$ to improve fuel quality. The dried 
TABLE 1: Elemental and chemical composition of coal.

\begin{tabular}{lcccccccccccccc}
\hline \multirow{2}{*}{ Year } & \multirow{2}{*}{ Sample } & \multicolumn{4}{c}{ Proximate analysis (wt.\%) } & \multicolumn{3}{c}{ Ultimate analysis (wt.\%) } & \multicolumn{2}{c}{ HHV } & \multirow{2}{*}{ Ref. } \\
& & Moisture & Volatiles & Ash & Fixed carbon & C & H & N & S & O & MJ/kg & \\
\hline 2017 & Coal & 8.59 & 68.55 & 6.62 & 16.14 & 64.49 & 7.22 & 2.09 & - & 26.20 & - & {$[52]$} \\
\hline 2017 & Bituminous coal & 4.18 & 30.56 & 15.38 & 49.88 & 79.31 & 4.72 & 1.03 & 1.3 & 13.38 & - & {$[53]$} \\
\hline 2016 & Bituminous coal & 4.18 & 30.56 & 15.38 & 49.88 & 79.31 & 4.72 & 1.03 & 1.3 & 13.38 & 25.44 & {$[54]$} \\
\hline 2016 & South African coal & 2.1 & 29.4 & 13.9 & 70.6 & 70.58 & 3.99 & 1.77 & 0.63 & 7.93 & 33.2 & {$[55]$} \\
\hline 2016 & Bituminous coal & - & 36.8 & 9.7 & 53.5 & 70.5 & 4.1 & 1.0 & - & 14.7 & - & {$[56]$} \\
\hline 2015 & Bituminous coal & - & 34.39 & 11.43 & 56.91 & 76.04 & 4.99 & 0.86 & 0.62 & 8.42 & - & {$[57]$} \\
\hline 2015 & Bituminous coal & 2.28 & 9.09 & 16.57 & 72.06 & 74.50 & 2.66 & 1.39 & 0.48 & 18.96 & 28.10 & {$[58]$} \\
\hline 2015 & Bituminous coal & 11.22 & 8.01 & 30.33 & 61.66 & 62.07 & 2.30 & 1.16 & 2.21 & 1.93 & 24.38 & {$[59]$} \\
\hline 2014 & Bituminous coal & 4.18 & 30.56 & 15.38 & 49.88 & 79.31 & 4.72 & 1.02 & 1.3 & 13.38 & 25.44 & {$[60]$} \\
\hline 2014 & Bituminous coal & 3.34 & 34.25 & 6.70 & 55.72 & 73.16 & 5.21 & 4.40 & 1.53 & 5.66 & - & {$[61]$} \\
\hline
\end{tabular}

TABLE 2: Elemental and chemical composition of lignocellulosic biomass.

\begin{tabular}{|c|c|c|c|c|c|c|c|c|c|c|c|c|c|c|}
\hline \multirow[b]{2}{*}{ Year } & \multirow[b]{2}{*}{ Biomass } & \multicolumn{4}{|c|}{ Proximate analysis (\%) } & \multicolumn{5}{|c|}{ Ultimate analysis (\%) } & \multicolumn{3}{|c|}{ Chemical composition (\%) } & \multirow[b]{2}{*}{ Ref. } \\
\hline & & Moisture & Volatiles & Ash & $\begin{array}{c}\text { Fixed } \\
\text { carbon }\end{array}$ & $\mathrm{C}$ & $\mathrm{H}$ & $\mathrm{N}$ & $S$ & $\mathrm{O}$ & Cellulose & Hemicellulose & Lignin & \\
\hline 2017 & $\begin{array}{c}\text { Sugarcane } \\
\text { bagasse }\end{array}$ & 6.21 & 82.38 & 2.94 & 8.47 & 45.3 & 7.92 & 0.15 & - & 46.6 & & & & [69] \\
\hline 2017 & $\begin{array}{c}\text { Sugarcane } \\
\text { bagasse }\end{array}$ & 8.5 & 84.00 & 5.86 & 1.64 & 45.0 & 5.78 & 1.75 & - & 47.4 & & & & [69] \\
\hline 2017 & Rice husk & 10.89 & 73.41 & 15.14 & 11.44 & 41.9 & 6.34 & 1.85 & 0.47 & 49.4 & & & & {$[70]$} \\
\hline 2017 & Rice husk & 9.5 & 67.6 & 16.6 & 6.3 & 49.2 & 2.2 & 0.40 & 0.06 & 48.1 & & & & {$[71]$} \\
\hline 2016 & $\begin{array}{c}\text { Sugarcane } \\
\text { bagasse }\end{array}$ & 5.4 & 80.2 & 3.1 & 11.3 & 44.8 & 5.87 & 0.24 & 0.06 & 48.9 & 47.6 & 39 & 11.2 & [72] \\
\hline 2016 & $\begin{array}{c}\text { Sugarcane } \\
\text { bagasse }\end{array}$ & 8.64 & 73.28 & 1.71 & 16.37 & 41.6 & 6.21 & 0.37 & 0.07 & 41.3 & & & & [73] \\
\hline 2016 & Rice husk & 8.8 & 59.2 & 26.2 & 14.6 & 35.6 & 4.5 & 0.19 & 0.02 & 59.7 & 35 & 33 & 23 & [74] \\
\hline 2015 & $\begin{array}{c}\text { Sugarcane } \\
\text { bagasse }\end{array}$ & 4.99 & 73.5 & 2.41 & 19.1 & 41.9 & 6.04 & 0.53 & 0.24 & 48.8 & $35-50$ & $20-30$ & $20-27$ & [75] \\
\hline 2015 & Rice husk & 4.7 & 69.3 & 15.8 & 10.2 & 39.8 & 5.10 & 1.09 & - & 53.8 & 40.2 & 24.3 & 18.1 & [76] \\
\hline 2015 & Rice husk & 3.56 & 67.93 & 14.84 & 13.67 & 44.8 & 6.35 & 0.42 & - & 48.3 & & & & [77] \\
\hline 2014 & $\begin{array}{c}\text { Sugarcane } \\
\text { bagasse }\end{array}$ & 4.99 & 73.5 & 2.41 & 19.1 & 41.9 & 6.04 & 0.53 & 0.24 & 48.8 & $35-50$ & $20-30$ & $2-27$ & [76] \\
\hline 2014 & $\begin{array}{c}\text { Sugarcane } \\
\text { bagasse }\end{array}$ & - & 90.02 & 1.33 & 9.60 & 47.1 & 6.14 & 0.30 & - & 46.4 & & & & [78] \\
\hline 2013 & Rice husk & 8.43 & 68.25 & 14.83 & 16.92 & 39.4 & 5.71 & 0.67 & 0.99 & 54.1 & 41.52 & 14.04 & 33.67 & [79] \\
\hline 2013 & Rice husk & 12.08 & 60.55 & 12.35 & 15.2 & 45.4 & 5.40 & 0.48 & 0.06 & 36.05 & & & & [80] \\
\hline
\end{tabular}

lumps of sewage sludge were disintegrated to fine powder. Inguanzo et al. suggested the size range of sewage sludge used for different pyrolysis experiments in fixed bed systems [89]. Table 4 reviews the elemental and chemical composition of sewage sludge obtained from wastewater treatment plants. The volatile matters range between $38 \%$ and $70 \%$ and ash contents between 1 and $12 \%$. As shown from the ultimate analysis, sewage sludge contains a higher percentage of carbon between $23 \%$ and $46 \%$ and a lower percentage of nitrogen and hydrogen contents. The extractives are slightly higher, about $7 \mathrm{wt} \%$ dry ash free, than that present in biomasses. These extractives are composed of fatty acids, steroids, and aliphatic compounds and these extractives can improve the liquid fuel properties such as viscosity and heating value and can provide ease in phase separation of liquid fuels. Sewage sludge contains a relatively higher nitrogen content than lignocellulosic biomass [96]. This comes from the protein fragments of samples and can favor its usage in fertilizer [97]. The proximate analysis reveals that the sewage sludge has a high ash content than lignocellulosic biomass, and this study shows that ash removal system should be installed with reactor while using this type of material. The ash obtained as a result of sewage sludge pyrolysis contains minerals such as quartz and calcite. The elemental analysis gives information regarding the mineral composition in terms of $\mathrm{Fe}, \mathrm{Ca}, \mathrm{Mg}$, and $\mathrm{K}$ which helps catalyze the pyrolysis reaction. Some heavy metals such as $\mathrm{Cr}, \mathrm{Ni}, \mathrm{Co}, \mathrm{Hg}, \mathrm{Cd}, \mathrm{Pb}$, and $\mathrm{Zn}$ are also present in sewage 
TABLE 3: Elemental and chemical composition of product obtained from coal, lignocellulosic biomass, sludge, and their blends.

\begin{tabular}{|c|c|c|c|c|c|c|c|c|c|}
\hline Sample name & $\begin{array}{c}\text { Volatile } \\
\text { matter }(\%)\end{array}$ & $\begin{array}{c}\text { Fixed } \\
\text { carbon }(\%)\end{array}$ & Ash (\%) & $\begin{array}{c}\text { Calorific } \\
\text { value }(\mathrm{MJ} / \mathrm{kg})\end{array}$ & C (\%) & $\mathrm{H}(\%)$ & $\mathrm{O}(\%)$ & N (\%) & Ref. \\
\hline Apricot stone biochar & 19.83 & 71.70 & 8.47 & 30.76 & & & & & \multirow{4}{*}{ [81] } \\
\hline Hazelnut shell biochar & 30.26 & 63.16 & 6.58 & 29.08 & & & & & \\
\hline Grapeseed biochar & 39.45 & 50.96 & 9.50 & 26.73 & & & & & \\
\hline Chestnut shell biochar & 34.32 & 60.32 & 5.36 & 25.86 & & & & & \\
\hline $\begin{array}{l}\text { Microalgae + sewage } \\
\text { sludge + coal mixtures }\end{array}$ & & & & & $9.80-15.89$ & & $17.24-53.65$ & & {$[82]$} \\
\hline \multirow{2}{*}{$\begin{array}{l}\text { (Bituminous } \\
\text { coal + peanut shell) } \\
\text { biochar } \\
\text { (Bituminous coal + wheat } \\
\text { straw) biochar }\end{array}$} & $45.12-8.46$ & $41.81-71.23$ & $9.53-12.03$ & $23.99-28.79$ & $61.72-79.99$ & $4.64-1.83$ & $21.38-2.07$ & $0.28-0.20$ & \multirow[t]{2}{*}{ [83] } \\
\hline & $35.65-8.67$ & $53.36-77.99$ & $8.15-11.82$ & $16.82-24.07$ & $49.81-70.29$ & $3.99-1.98$ & $36.39-14.95$ & $1.04-0.45$ & \\
\hline \multirow{3}{*}{$\begin{array}{l}\text { Sewage sludge biochar } \\
\text { (Sewage sludge + rice } \\
\text { husk) biochar } \\
\text { (Sewage } \\
\text { sludge + sawdust) biochar }\end{array}$} & $43.9-12.5$ & $4.1-2.7$ & $52-84.1$ & & $25.7-9.4$ & $2.8-0.3$ & $66.8-89.5$ & $4.7-1.1$ & \multirow{3}{*}{ [84] } \\
\hline & $63.2-31.6$ & $0.4-2.9$ & $36.4-65.5$ & - & $35.8-26.3$ & $3.9-0.6$ & $57.8-71.3$ & $2.8-1.8$ & \\
\hline & $75.1-44.8$ & $2.1-5.7$ & $22.8-52.5$ & & $42.5-39.5$ & $5.0-1.5$ & $50.9-56.6$ & $1.6-2.4$ & \\
\hline $\begin{array}{l}\text { (Dewatered sewage } \\
\text { sludge + pine sawdust) } \\
\text { biochar }\end{array}$ & 5.64 & 48.36 & 46.0 & & 35.87 & 1.66 & 13.89 & 2.06 & {$[85]$} \\
\hline
\end{tabular}

sludge [97]. Xu et al. found that sewage sludge contained $60.34 \%$ of volatile matters and a lower percentage of carbon content about $36.8 \%$ with a $\mathrm{HHV}$ of $14.90 \mathrm{MJ} / \mathrm{kg}$ [98]. According to the findings of Nadia et al., sewage sludge obtained from municipal wastewater treatment plant contained a higher percentage of carbon and oxygen and has a lower percentage of fixed carbon, ash, and nitrogen [84]. A higher amount of volatile matter makes sewage sludge a better candidate as a feedstock for thermal conversion. Sijiang et al. concluded that higher moisture content in the sewage sludge can lead to the hydrogen-rich fuel which can be compensated by the addition of volatile matters [85]. Xiong et al. described that sewage sludge contained a higher percentage of protein about $27 \%$ and a lower percentage of extractives about $9.9 \%$ [99].

\subsection{Thermal Coconversion}

3.4.1. Copyrolysis. Copyrolysis is a simple and effective technique to obtain ideal liquid fuel or bio-oil. It is a process by which two or more different materials are mixed and used as feedstock. Copyrolysis of biomass can change the properties, quantity, and quality of liquid oil with no improvement in the system process. Copyrolysis has better applications in the industry than thermal cracking because of its attractive production and promising features. The successful feature of this technique is the combined effect of different materials. High yield of oil by using different blends of biomass with sewage sludge and coal has originated from hydrocarbons like paraffin, isoparaffins, olefins, naphthenes, and aromatics and a noncondensable gas [100]. The other main advantage of copyrolysis method is that it can reduce many environmental problems by reducing the amount of waste and avoiding disposal as landfills [101].
The operating method and conditions of copyrolysis are the same as that of simple pyrolysis. The process is performed in a reactor system with optimum operating temperatures in the absence of an oxidizing environment to obtain liquid oils. There are three basic steps of the copyrolysis process: the preparation of feedstock, copyrolysis, and condensation [102]. Inert gas is optionally used to displace vapors from the pyrolysis zone. Residence time plays a vital role in minimizing secondary reactions and maximizing oil yield, and suitable residence time suggested by researchers is less than 2 seconds [103].

Table 4 shows a detailed description of the literature survey of the different types of biomass/coal and biomass/ sewage sludge blends through copyrolysis, various types of reactors operated under different conditions and providing various products. Akhtar and Amin reviewed that oil yield obtained by the copyrolysis process of biomass, sewage sludge, and coal is also affected by many parameters including the type of biomass, temperature, heating rate, reaction time, and particle size of feed. $45 \mathrm{wt} . \%$ of the oil can be obtained by subjecting the biomass blend at the typical temperature range of $400-600^{\circ} \mathrm{C}$, and the optimum temperature at which the maximum oil is obtained depends upon the type and characteristics of blends [104]. According to different reviews, the other very important parameter is the ratio of different blends which has a direct influence on the production of oil $[105,106]$. The type of reactors can also influence the efficiency of copyrolysis process and can affect the quality and quantity of the product. The best conditions for obtaining a high yield of bio-oil are the high heating rate, moderate temperature, and short residence time. Each reactor has promising features to obtain a specific type of products. For example, for fast pyrolysis to obtain maximum liquid product, fluidized bed reactors are preferred over fixed bed reactors as their operation and scalability are 
TABLE 4: Elemental and chemical composition of sewage sludge.

\begin{tabular}{|c|c|c|c|c|c|c|c|c|c|c|c|c|c|c|}
\hline \multirow[t]{2}{*}{ Year } & \multirow[t]{2}{*}{ Sewage sludge } & \multicolumn{4}{|c|}{ Proximate analysis } & \multicolumn{5}{|c|}{ Ultimate analysis } & \multirow{2}{*}{$\begin{array}{c}\mathrm{HV} \\
\mathrm{MJ} / \mathrm{kg}\end{array}$} & \multicolumn{2}{|c|}{$\begin{array}{l}\text { Biochemical } \\
\text { composition }\end{array}$} & \multirow[t]{2}{*}{ Ref. } \\
\hline & & M (\%) & VM (\%) & FC (\%) & Ash (\%) & C (\%) & $\mathrm{H}(\%)$ & $\mathrm{N}(\%)$ & S (\%) & $\mathrm{O}(\%)$ & & Protein & Extr. & \\
\hline 2017 & Municipal & 5.1 & 60.34 & 1.13 & 33.43 & 36.88 & 4.94 & 5.03 & 1.14 & 52.01 & 14.90 & - & - & {$[90]$} \\
\hline 2017 & $\begin{array}{c}\text { Wastewater treatment } \\
\text { plant }\end{array}$ & 7 & 50 & 3 & 40 & 27.9 & 4.7 & 4.5 & 1.4 & 34.6 & 12.50 & 28 & 3.5 & {$[84]$} \\
\hline 2016 & $\begin{array}{c}\text { Wastewater treatment } \\
\text { plant }\end{array}$ & 5.6 & 54.2 & 8.6 & 37.2 & 40.6 & 7.1 & 7.7 & 3.3 & 41.2 & 11.1 & - & - & {$[91]$} \\
\hline 2016 & $\begin{array}{c}\text { Wastewater treatment } \\
\text { plant }\end{array}$ & 7.4 & 63.1 & 7.1 & 22.5 & 38.0 & 5.1 & 6.9 & 1.2 & 19.0 & - & - & - & {$[92]$} \\
\hline 2016 & $\begin{array}{c}\text { Wastewater treatment } \\
\text { plant }\end{array}$ & 5.8 & 54.1 & 6.0 & 34.2 & 34.9 & 4.8 & 4.5 & 1.1 & 14.8 & - & - & - & {$[93]$} \\
\hline 2015 & $\begin{array}{c}\text { Wastewater treatment } \\
\text { plant }\end{array}$ & 8.71 & 61.11 & 9.20 & 26.89 & 45.16 & 7.20 & 7.69 & - & 27.59 & 16.18 & - & - & [94] \\
\hline 2014 & $\begin{array}{c}\text { Wastewater treatment } \\
\text { plant }\end{array}$ & 4.43 & 68.57 & 16.42 & 15.01 & 53.24 & 7.39 & 6.12 & - & 33.25 & 24.2 & - & - & [95] \\
\hline
\end{tabular}

simpler. Guo et al. investigated the co-pyrolytic behavior of biomass and coal and low heating rates $\left(10-50^{\circ} \mathrm{C} / \mathrm{min}\right)$ and higher heating rates $\left(10^{\circ} \mathrm{C} / \mathrm{min}\right)$ in tubular reactor and furnace and concluded that under inert atmospheric condition, the two fuels experience autonomous thermal conversion, but lower heating rates are better than higher heating rates in terms of better conversion [107]. Wang et al. explored the effect of residence time $(30-150 \mathrm{~min})$ on copyrolysis product of sewage sludge and biomass and concluded that extended residence times elevate the $\mathrm{pH}$ and ash contents of the biochars, but these conditions decreased the $\mathrm{C}, \mathrm{N}$, and $\mathrm{H}$ contents [108].

3.4.2. Cocombustion. Cocombustion is a high-temperature thermochemical conversion technique in which sludge/coal, coal/biomass, and biomass/sludge blends undergo thermal degradation and release volatile matter such as $\mathrm{CO}, \mathrm{CO}_{2}$, $\mathrm{H}_{2} \mathrm{O}, \mathrm{H}_{2}, \mathrm{CH}_{4}$, and tar. Among all thermochemical conversion techniques, cocombustion is the only technique used to produce both heat and electricity. The advantages include low cost, high efficiency, and low emission of SOx and NOx. The main drawback of using cocombustion technique is its scale forming tendency in the boiler and limitation in using alkali metals. Due to unwanted changes in ash configurations, the proportion of biomass is usually kept limited to approximately $10 \%$ of the fuel intake. Cocombustion of biomass with coal is the most important technique with respect to the economic and environmental benefits to curb $\mathrm{CO}_{2}$ at a certain level [109]. Economically lower capital investment and lower amount of raw material are required, and the risk factor is minimal while using cocombustion techniques. Cocombustion techniques are further classified into three types; one is a direct cocombustion in which biomass or waste is directly fed into the reactor with coal (Figure 5).

In this process, both feedstocks are milled directly and fed individually into the reactor. It has low flexibility; also, the possibility of producing slag and fouling is high. Other is the indirect cocombustion in which separate gasifier should be installed to convert solid feedstock into syngas. It is a more flexible technique, and the chance of slag formation and fouling is lower. Parallel cocombustion includes the setting up of a separate boiler to produce steam, which is useful in producing electricity. The parallel technique allows a greater amount of biomass and deals with contamination issues. The synergetic effect during cocombustion is usually articulated in terms of the high amount of gases, the high reactivity of the char during cocombustion, and reduction in harmful emission during cocombustion. Cocombustion operating parameters have a large influence on product quality and emission control. Xiao et al. studied the performance of sewage sludge and straw blends in cocombustion environment at heating rate of 10 , 20 , and $40^{\circ} \mathrm{K} \cdot \mathrm{min}^{-1}$ and concluded that better efficiency of cocombustion achieved at higher heating rates [111]. Munir et al. investigated the effect of the thermal ratio of different types of biomass in addition to municipal waste in cocombustion environment and found that the adding of biomass enlarged NO lessening under air stage conditions [112].

3.5. Blending Impact. Biomass, coal, and sewage sludge blends in feedstock greatly influence the amount and properties of products. The following are the key points.

3.5.1. Blending Impact on Tar Release. Tar is defined as a mixture of aromatic compounds and derivatives of aromatic compounds produced under the partial oxidation environment at ambient to lower temperatures. The tar content produced during copyrolysis of lignocellulosic biomass, coal, and sewage sludge blends is one of the key factors affecting the succeeding process stages. It is one of the most stimulating elements of the syngas. The main factors that affect the yield of tar during copyrolysis are the type of feedstock and temperature. The blending of coal, sewage sludge, and lignocellulosic biomass particles can lower the yield of tar compared to the pyrolysis of individual feedstocks [113, 114]. Kumabe et al. found that increasing biomass ratio in a blend of lignocellulosic biomass and coal slightly decreased the yield of tar in a downdraft fixed bed reactor at $900^{\circ} \mathrm{C}$ [50]. Pinto et al. used a blend of $80 \%$ coal and $20 \%$ pine wood 


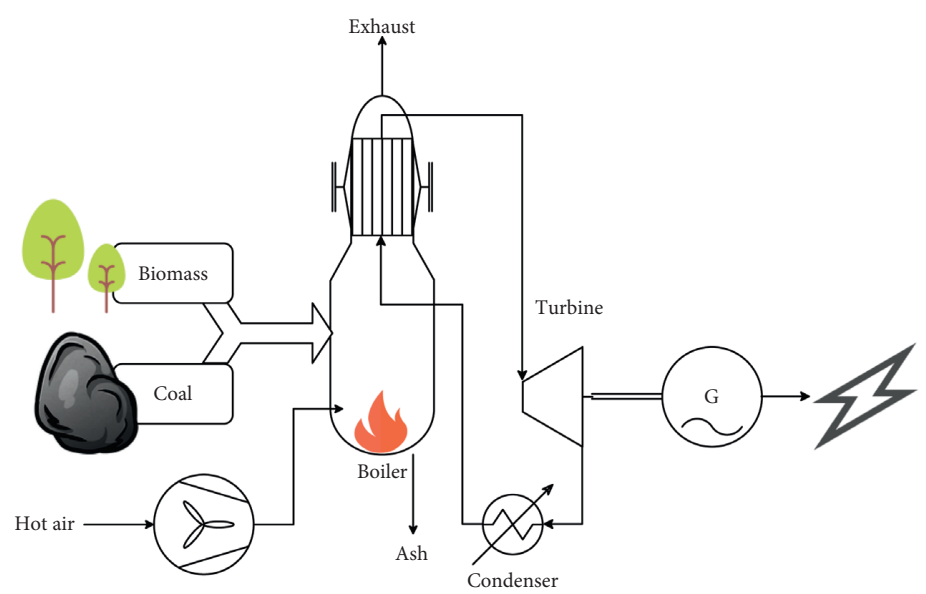

(a)

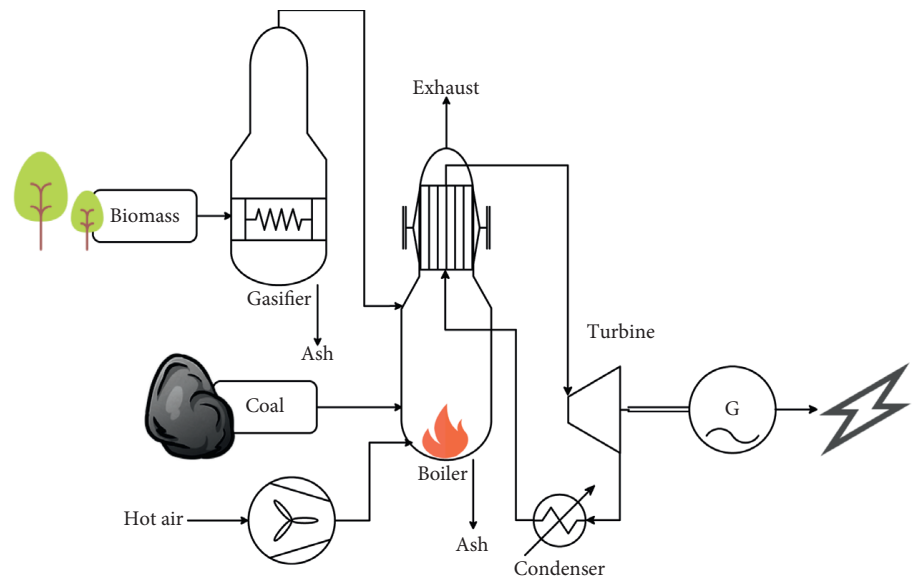

(b)

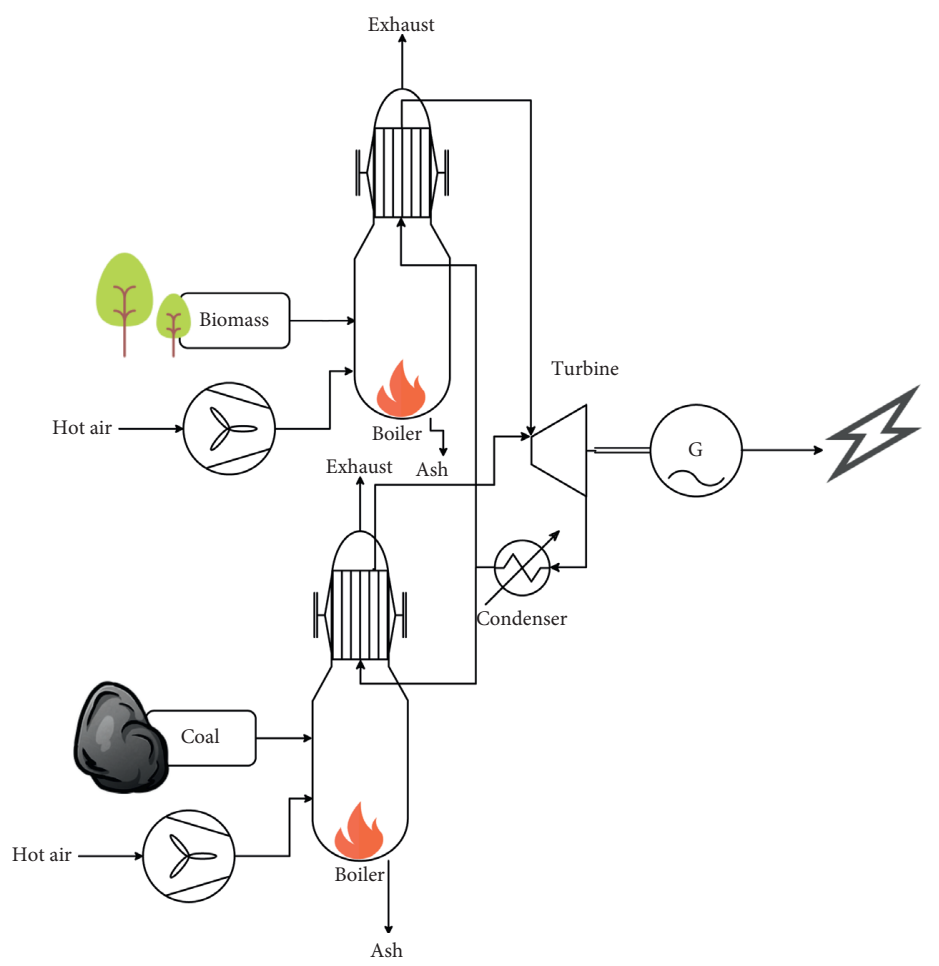

(c)

FIgURE 5: Cocombustion techniques: (a) direct cocombustion, (b) indirect cocombustion, and (c) parallel cocombustion [110]. 
waste in a fluidized bed reactor operating at atmospheric pressure and at a temperature of $850-900^{\circ} \mathrm{C}$ [115]. They found that an increase in the polyethylene waste into the blend can cause an increase in tar release which can be attributed to the breaking down of the feed element into smaller elements by thermal cracking. This can be avoided by blending three materials: coal, polyethylene waste, and pine that brings down tar release. This effect can also be reduced by using a dolomite catalyst during the cocombustion of coal and biomass/waste mixtures [116]. Collot et al. experimented on a blend of Polish coal and forest residue and found no effect on synergy [117]. Aznar et al. and Andre et al. also acknowledged higher tar yield with an increase in the ratio of biomass percentage of the coal/biomass blend and found a greater impact on synergetic effect during cocombustion at specified conditions $[49,118]$. More investigation is still required to briefly explain the issue regarding tar release and its impact on the synergy effect during thermal coconversion of different coal, lignocellulosic biomass, and sewage sludge blends.

3.5.2. Blending Impact on Alkali and Ash. One of the major problems during thermal coconversion of blends is the deposition and formation of alkali and ash which can cause slagging, agglomeration, or fouling on the heat transfer surface of furnace and boiler because of the inorganic constituents of lignocellulosic biomass, waste, and coal mixture. The type of feedstock, operating condition, and flow dynamics have great influence on the characteristics of ash formation. Usually, ash obtained from lignocellulosic biomass has a low melting temperature as compared to ash obtained from coal, so it is necessary to pay attention to the behavior of ash produced from lignocellulosic biomass and coal mixture during copyrolysis or cocombustion. It is necessary to understand the different forms of alkali constituent present in blends and chemical reaction with a specific condition to investigate the ash produced from coal and biomass blends during thermal coconversion. Zheng et al. detected that the percentage of potassium in the fly ash is almost like the ash in the straw during combustion and the cocombustion process [119]. He determined that if the ash composition of the fuel and straw share are known, the total percentage of potassium in fly ash can be predicted. Condensation, vaporization, and agglomerations are the mechanisms used to produce ash during copyrolysis and cocombustion. Alkali metal and chloride present in biomass vaporize and $\mathrm{KCl}, \mathrm{NaCl}, \mathrm{K}_{2} \mathrm{SO}_{4}$, and $\mathrm{Na}_{2} \mathrm{SO}_{4}$ are formed. Strand et al. suggested two primary ways used to condense these vapors into particles: a homogeneous condensation in which vapor condenses into agglomerates and then into a particle, and the other is a heterogeneous condensation where the vapor on the surface of an existing particle entrains in the flue gas [120]. Wu et al. somewhat agree that the abrasive ash particles formed by mechanisms such as coalescence and shedding and fine particles are formed by vaporization and condensation mechanisms [121].
3.5.3. Blending Impact on Char Characteristics. Bernardo et al. investigated the physical and chemical properties of chars obtained in the copyrolysis of three waste plastic, tires, and pine mixtures [122]. He concluded that the yield of char increases with the addition of tire because the addition of plastic waste in copyrolysis of pine biomass had no effect on char yield. The quality of char obtained from copyrolysis has a greater influence on the calorific value. Paradela et al. found that the char products obtained from the copyrolysis of a blend of biomass and plastic wastes have higher HHV than char obtained from pyrolysis of coal alone [116]. Brebu et al. concluded that char obtained from pyrolysis of pine cone contains higher oxygen content and lower calorific value than the char obtained from copyrolysis [123]. It was also found that the char contains less sulfur, so it can be easily used for the fuel in cocombustion of coal and lignocellulosic biomass. Another advantage of the char obtained from copyrolysis is its potential application as an absorbent to remove heavy metals.

\section{Behavior of Thermal Coconversion through TGA}

The behavior of thermal coconversion or synergetic effect of different types of coal, lignocellulosic biomass, and sewage sludge can be obtained by using thermal analysis tools such as thermogravimetric (TGA), derivative thermogravimetric (DTG), and differential scanning calorimetric (DSC) analyses (Table 5). TGA is an important tool to measure the percentage of mass loss with respect to temperature and time and to examine the thermal decomposition behavior during pyrolysis. A detailed review of TGA and kinetics of degradation of substances during pyrolysis can help in plan and develop the pyrolysis process [132]. According to different results obtained by TGA, pyrolysis of biomass is usually divided into three main stages; in the first stage, removal of moisture takes place at the temperature range of less than $200^{\circ} \mathrm{C}$. In the second stage, from a temperature range of $200-600^{\circ} \mathrm{C}$, the main decomposition of substance occurs due to devolatilization and oxidation.

Usually, during this stage cellulose, hemicellulose and lignin decompose and this stage is further subdivided into two parts; in the first part, at lower temperature range $\left(200-450^{\circ} \mathrm{C}\right)$, cellulose and hemicellulose of any biomass sample decompose, and at a higher temperature $\left(455^{\circ} \mathrm{C}\right.$ to $1000^{\circ} \mathrm{C}$ ), lignin is thermally degraded. In the third stage, at a temperature above $600^{\circ} \mathrm{C}$, the reduction in the decomposition reaction occurs due to oxidation of char and remaining substance. The leftover material after complete burning is called ash. Ash contains different types of metallic substances that act as catalysts during the pyrolysis process. The weight of the sample in TGA can be varied from 1 to $150 \mathrm{mg}$, and sample weight greater than $10 \mathrm{mg}$ is often reported with a sensitivity of $0.01 \mathrm{mg}$. However, lower sample weight of $1-2 \mathrm{mg}$ is usually preferred, making sure the interior sample temperature remains close to the measured furnace 
TABLE 5: Thermal coconversion of different samples by using copyrolysis and cocombustion techniques.

\begin{tabular}{|c|c|c|c|c|c|c|c|c|c|c|}
\hline \multirow[b]{2}{*}{ Year } & \multirow[b]{2}{*}{ Sample } & \multirow{2}{*}{$\begin{array}{l}\text { Sample } \\
\text { ratio } \\
(\%)\end{array}$} & \multirow[b]{2}{*}{$\begin{array}{l}\text { Reactor } \\
\text { type }\end{array}$} & \multicolumn{4}{|c|}{ Experimental conditions } & \multirow[b]{2}{*}{ Product } & \multirow[b]{2}{*}{ Observations } & \multirow[b]{2}{*}{ Ref. } \\
\hline & & & & Temperature & $\begin{array}{l}\text { Residence } \\
\text { time }\end{array}$ & Heating rate & Feed & & & \\
\hline 2017 & $\begin{array}{c}\text { Sewage } \\
\text { sludge }+ \text { lignocellulosic } \\
\text { biomass }\end{array}$ & $\begin{array}{l}\text { SS :B } \\
20: 80 \\
40: 60 \\
60: 40 \\
80: 20\end{array}$ & $\begin{array}{l}\text { Moving } \\
\text { bed } \\
\text { reactor }\end{array}$ & $25-1200^{\circ} \mathrm{C}$ & $30 \mathrm{~min}$ & - & $200 \mathrm{~kg} / \mathrm{h}$ & $\begin{array}{c}\text { Syngas } \\
\left(\mathrm{H}_{2}+\mathrm{CO}\right)\end{array}$ & $\begin{array}{c}\mathrm{H}_{2} \text { content } \\
\text { increased from } \\
33 \% \text { to } 47 \% \text { in } \\
\text { blending of } \\
60 \% \mathrm{SS}+40 \% \\
\text { biomass }\end{array}$ & {$[124]$} \\
\hline 2017 & $\begin{array}{c}\text { Coal + lignocellulosic } \\
\text { biomass }\end{array}$ & $\begin{array}{l}\text { Coal : B } \\
100: 0 \\
50: 50\end{array}$ & $\begin{array}{l}\text { Tubular } \\
\text { furnace }\end{array}$ & $25-900^{\circ} \mathrm{C}$ & $40 \mathrm{~min}$ & $10^{\circ} \mathrm{C} / \mathrm{min}$ & $25 \mathrm{~g}$ & Ash & $\begin{array}{l}\text { Ash properties } \\
\text { were } \\
\text { performed for } \\
\text { leaching test }\end{array}$ & {$[57]$} \\
\hline 2016 & $\begin{array}{l}\text { Rice husk + plastic } \\
\text { waste }\end{array}$ & $\begin{array}{c}\text { RH: } \\
\text { PW } \\
20: 80 \\
30: 70 \\
40: 60 \\
50: 50\end{array}$ & $\begin{array}{l}\text { Batch } \\
\text { reactor }\end{array}$ & $25-800^{\circ} \mathrm{C}$ & $35 \mathrm{~min}$ & $5-6^{\circ} \mathrm{C} / \mathrm{min}$ & - & Bio-oil & $\begin{array}{c}\text { Around } 66 \% \text { of } \\
\text { liquid } \\
\text { compounds } \\
\text { can be obtained } \\
\text { by copyrolysis } \\
\text { of } 20 \% \text { of } \mathrm{RH} \\
\text { blended with } \\
\text { plastic waste. } \\
\text { More than } 20 \% \\
\mathrm{RH} \text { is not } \\
\text { favored for } \\
\text { liquid oil } \\
\text { production }\end{array}$ & {$[125]$} \\
\hline 2016 & $\begin{array}{c}\text { Coal }+ \text { lignocellulosic } \\
\text { biomass }\end{array}$ & $\begin{array}{c}\text { Coal : B } \\
0: 100 \\
25: 75 \\
50: 50 \\
75: 25 \\
100: 0 \\
\end{array}$ & $\begin{array}{l}\text { Moving } \\
\text { bed } \\
\text { pyrolyzer }\end{array}$ & $500-850^{\circ} \mathrm{C}$ & $2 \mathrm{~h}$ & - & $200 \mathrm{~g} / \mathrm{h}$ & $\begin{array}{l}\text { Gases and } \\
\text { tar }\end{array}$ & $\begin{array}{l}\text { Tar and gas } \\
\text { yields showed } \\
\text { an incremental } \\
\text { trend with the } \\
\text { increase in } \\
\text { biomass ratio }\end{array}$ & [99] \\
\hline 2015 & $\begin{array}{l}\text { Sewage sludge + rice } \\
\text { husk }\end{array}$ & $\begin{array}{l}\text { SS }: \text { RH } \\
50: 50\end{array}$ & $\begin{array}{l}\text { Vacuum } \\
\text { fixed bed } \\
\text { reactor }\end{array}$ & $900^{\circ} \mathrm{C}$ & $2 \mathrm{~h}$ & $10^{\circ} \mathrm{C} / \mathrm{min}$ & $10 \mathrm{~g}$ & $\begin{array}{l}\text { Gas } \\
\text { products }\end{array}$ & $\begin{array}{l}\text { Higher amount } \\
\text { of } \mathrm{SS} \text { promoted } \\
\mathrm{CO}_{2}-\mathrm{C} \text { and } \\
\mathrm{H}_{2} \mathrm{O}-\mathrm{C} \\
\text { gasification } \\
\text { reactions }\end{array}$ & {$[126]$} \\
\hline 2015 & $\begin{array}{l}\text { Bituminous coal + rice } \\
\text { husk }\end{array}$ & $\begin{array}{c}\text { B : coal } \\
0: 100 \\
20: 80 \\
40: 60 \\
80: 40 \\
100: 0 \\
\end{array}$ & $\begin{array}{l}\text { Fixed bed } \\
\text { reactor }\end{array}$ & $\mathrm{Up}$ to $900^{\circ} \mathrm{C}$ & $15 \mathrm{~min}$ & $\begin{array}{l}10-30^{\circ} \mathrm{C} / \\
\min \end{array}$ & - & Biofuels & $\begin{array}{c}\text { Experimental } \\
\text { and calculated } \\
\text { value observed } \\
\text { differently for } \\
\text { blended } \\
\text { samples } \\
\end{array}$ & [127] \\
\hline 2015 & $\begin{array}{c}\text { Sugarcane } \\
\text { bagasse + sewage sludge }\end{array}$ & $\begin{array}{l}\text { SS : SB } \\
50: 50 \\
25: 75\end{array}$ & Pyrolyzer & $25-600^{\circ} \mathrm{C}$ & - & $10^{\circ} \mathrm{C} / \mathrm{min}$ & $10 \mathrm{mg}$ & Biofuels & $\begin{array}{c}\text { Cocombustion } \\
\text { process showed } \\
\text { lower } \\
\text { activation } \\
\text { energy } \\
\end{array}$ & [128] \\
\hline 2014 & $\begin{array}{c}\text { Sewage } \\
\text { sludge }+ \text { lignocellulosic } \\
\text { biomass }\end{array}$ & $\begin{array}{l}\text { SS :B } \\
0: 100 \\
30: 70 \\
50: 50 \\
70: 30 \\
100: 0\end{array}$ & TG-MS & $40-800^{\circ} \mathrm{C}$ & - & $10^{\circ} \mathrm{C} / \mathrm{min}$ & $10 \mathrm{mg}$ & $\begin{array}{l}\text { Gas } \\
\text { products }\end{array}$ & $\begin{array}{c}\mathrm{CO}_{2}, \mathrm{SO}_{2}, \mathrm{NH}_{3} \text {, } \\
\mathrm{HCN} \text {, and } \mathrm{NO} \\
\text { were mainly } \\
\text { gaseous species } \\
\text { produced at } \\
\text { temperature of } \\
523-873^{\circ} \mathrm{K} \\
\end{array}$ & {$[60]$} \\
\hline
\end{tabular}


TABle 5: Continued.

\begin{tabular}{|c|c|c|c|c|c|c|c|c|c|c|}
\hline \multirow[b]{2}{*}{ Year } & \multirow[b]{2}{*}{ Sample } & \multirow{2}{*}{$\begin{array}{c}\text { Sample } \\
\text { ratio } \\
(\%)\end{array}$} & \multirow[b]{2}{*}{$\begin{array}{l}\text { Reactor } \\
\text { type }\end{array}$} & \multicolumn{4}{|c|}{ Experimental conditions } & \multirow[b]{2}{*}{ Product } & \multirow[b]{2}{*}{ Observations } & \multirow[b]{2}{*}{ Ref. } \\
\hline & & & & Temperature & $\begin{array}{l}\text { Residence } \\
\text { time }\end{array}$ & Heating rate & Feed & & & \\
\hline 2013 & $\begin{array}{c}\text { Sewage sludge + rice } \\
\text { husk }\end{array}$ & $\begin{array}{c}\text { SS }: \text { RH } \\
0: 100 \\
10: 90 \\
20: 80 \\
30: 70 \\
50: 50 \\
70: 30 \\
100: 0\end{array}$ & $\begin{array}{l}\text { Fixed bed } \\
\text { reactor }\end{array}$ & $25-900^{\circ} \mathrm{C}$ & $1-2 s$ & $10^{\circ} \mathrm{C} / \mathrm{min}$ & $2 \mathrm{~g}$ & $\begin{array}{l}\text { Bio-oil, } \\
\text { biogas }\end{array}$ & $\begin{array}{l}\text { Without } \\
\text { external heat } \\
\text { source, } \\
\text { copyrolysis } \\
\text { could be the } \\
\text { technology to } \\
\text { dispose } \\
\text { excessive } \\
\text { sludge }\end{array}$ & [129] \\
\hline 2013 & $\begin{array}{c}\text { Sewage } \\
\text { sludge }+ \text { biomass }\end{array}$ & $\begin{array}{c}\text { SS : B } \\
0: 100 \\
100: 0 \\
90: 10 \\
80: 20 \\
70: 30 \\
60: 40\end{array}$ & $\begin{array}{l}\text { Fixed bed } \\
\text { tubular } \\
\text { reactor }\end{array}$ & $25-800^{\circ} \mathrm{C}$ & - & $40^{\circ} \mathrm{C} / \mathrm{min}$ & $10 \mathrm{mg}$ & $\begin{array}{l}\text { Bio-oil, } \\
\text { biogas }\end{array}$ & $\begin{array}{l}\text { Presence of } \\
\text { petroleum } \\
\text { sludge } \\
\text { promotes } \mathrm{NH}_{3} \\
\text { and } \mathrm{HCN} \\
\text { formation with } \\
\text { biomass } \\
\text { coconversion }\end{array}$ & {$[130]$} \\
\hline 2012 & $\begin{array}{c}\text { Biomass + waste } \\
\text { materials }\end{array}$ & $\begin{array}{c}\text { B: WM } \\
30: 70 \\
50: 50\end{array}$ & Autoclave & $450^{\circ} \mathrm{C}$ & $15 \mathrm{~min}$ & $5^{\circ} \mathrm{C} / \mathrm{min}$ & - & $\begin{array}{l}\text { Bio-oil, } \\
\text { char, } \\
\text { gases }\end{array}$ & $\begin{array}{l}\text { A recovery of } \\
63-81 \% \text { of the } \\
\text { pyrolysis oils } \\
\text { was observed }\end{array}$ & {$[94]$} \\
\hline 2011 & $\begin{array}{c}\text { Sewage sludge + rice } \\
\text { husk }\end{array}$ & $\begin{array}{l}\text { SS : RH } \\
70: 30 \\
50: 50 \\
30: 70\end{array}$ & $\begin{array}{l}\text { Fluidized } \\
\text { bed } \\
\text { reactor }\end{array}$ & $500-650^{\circ} \mathrm{C}$ & $2 \mathrm{~s}$ & $30^{\circ} \mathrm{C} / \mathrm{min}$ & - & Bio-oil & $\begin{array}{l}\text { Combination } \\
\text { of feedstock } \\
\text { helps in } \\
\text { maximizing the } \\
\text { volume of } \\
\text { feedstock for } \\
\text { energy } \\
\text { conversion via } \\
\text { pyrolysis }\end{array}$ & [131] \\
\hline
\end{tabular}

temperature. The sample can be loaded in TGA as a fine powder or small pieces. DTG is a simple analytical tool to determine the amount of mass loss rate as a function of temperature. By examining the DTG curves, the temperature at which maximum rate mass loss appears can be determined by the position of the peaks in the curve. It is also used to find out the kinetic parameters (activation energy, preexponential factor, and order of reaction) of different organic materials during isothermal and nonisothermal conditions.

4.1. Thermogravimetric Analysis of Coal/Biomass Blends. The thermal coconversion of lignocellulosic biomass and coal blends has the advantage of reducing greenhouse gas emissions, such as sulfur oxides (SOx) and nitrogen oxides (NOx) [5]. The conversion of different types of lignocellulosic biomass such as sugarcane bagasse and rice husk blended with coal can be easily realized cheaply with minor modifications in the current coal operating plants to adopt the use of blend. Coconversion of coal and lignocellulosic biomass gives the advantage of using cleaner feedstock to dispose of wastes/biomass safely and economically [133]. Cothermal characteristics of coal and lignocellulosic biomass blends can be examined widely by thermal analytical techniques such as
TG, DTG, and DTA. TGA can rapidly assess the fuel value, the initial temperature at which degradation of component starts, and the final temperature at which degradation of component ends, and other characteristics such as maximum reactivity temperature, the rate of maximum reactivity, and amount of final residue. Thermal methods such as TG, DTG, and DTA have been used extensively to study a variety of thermal characteristics and parameters for the thermal conversion of different materials with coal. Thermal analysis can be used also to estimate kinetic parameters of different thermal processes. The main concern of the thermogravimetric study is to show that the decrease in particle size can cause a decline in ignition temperature. Thermal analysis of different coal and lignocellulosic biomass samples showed different stages in terms of temperature ranges during pyrolysis, combustion, and gasification processes. In coalbiomass blends, three different stages can be commonly observed. During the first stage, removal of moisture is carried out, and during the second stage, decomposition of cellulose and hemicellulose components occurs, and in the third stage, lignin degradation can be observed. By using the blends of biomass and coal, the decomposition of biomass is more dominant in the second stage than the decomposition of coal and the third stage is decomposition of coal with 


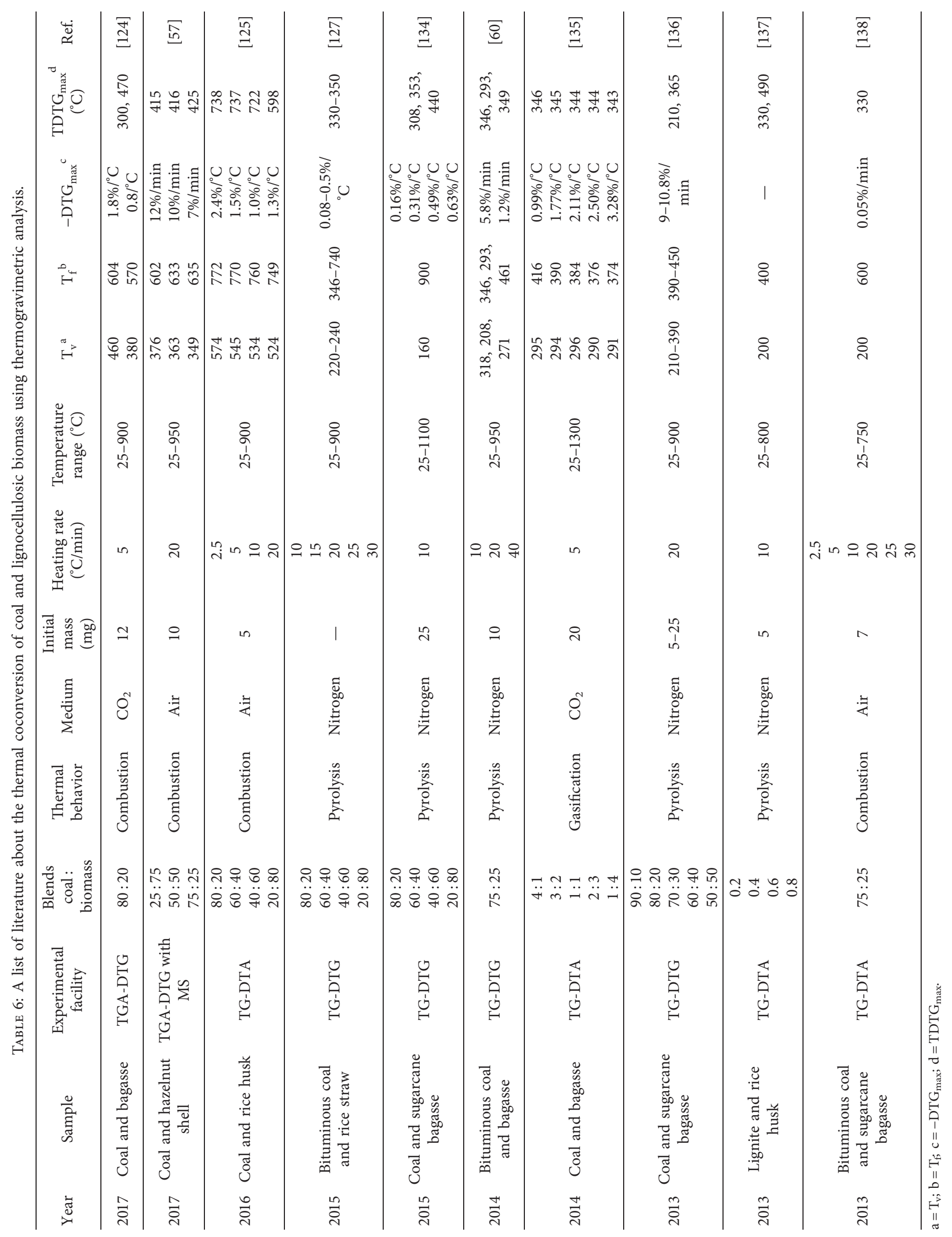


residual biomass. The major gaseous pollutants released from the thermal processes $\mathrm{CO}, \mathrm{CO}_{2}, \mathrm{CH}_{4}, \mathrm{NO}$, and $\mathrm{SO}_{2}$ were studied previously by TG-DTA. The thermal behavior of the material during thermal analysis techniques depend on heating rates $\left(5,10,20,30,40,50\right.$, and $\left.100^{\circ} \mathrm{C} / \mathrm{min}\right)$, reacting medium or environment (inert and oxidative by using $\mathrm{N}_{2}$, argon, $\mathrm{O}_{2}$, and $\mathrm{CO}_{2}$ ), mass and size of the sample used, and temperature ranges to be operated. These parameters can affect the product distribution and percentage of solid-liquid and gaseous fuels. Knowledge of these parameters can help to optimize the process. Table 6 gives a detailed description of a literature survey on the thermal behavior of various biomass and coal blends using different thermal analysis techniques. The commonly used blend ratios are $1: 1,2: 3,3: 4,4: 3$, and $3: 2$. Recently, Kandasamy Jayaraman et al. studied coal and biomass blends and they concluded that by increasing the ratio of biomass in the blends, the mass loss percentage increases, indicating the high reactivity of samples, and the activation energies were also increased by increasing biomass ratio in the blends [57]. Betancur et al. studied that coal and biomass blends increased combustion efficiency [124]. Blends showed lower ignition temperatures, and activation energies were decreased in the $\mathrm{CO}_{2}$ environment as compared to $\mathrm{N}_{2}$. Guangwei Wang et al. stated the synergistic effect of the combustion process of coal and biomass blends was prevalent as they increased the ignition performance by increasing the ratio of biomass [125]. Li et al. studied the copyrolysis of the coal and biomass blends and indicated the deviations in weight fractions [127].

\subsection{Thermogravimetric Analysis of Sewage Sludge/Biomass} Blends. Cothermal processes such as copyrolysis and cocombustion of sewage sludge with different types of lignocellulosic biomass can be applied for converting sewage sludge into useful energy and construction materials [139]. The other advantage of copyrolysis and cocombustion can help in reducing hazardous emissions to the atmosphere. Sludge has a low HHV, so burning of sewage sludge alone is neither cost-effective nor environmentally friendly. The blending of sewage sludge with lignocellulosic biomass material can make burning easier. The physical and chemical properties of the different materials used can affect the characteristics of the thermal process and residue obtained [140]. TGA is effective in studying the thermal behavior and characteristics of combustion of sewage sludge, biomass, coal, and other materials [141, 142]. It is an important technique to measure the percentage of mass loss of a sample with respect to temperature and time and to examine the thermal decomposition behavior during copyrolysis and cocombustion. It is also helpful in studying the kinetics of degradation of organic material during copyrolysis and cocombustion processes. Thermal degradation is a key element in designing sustainable copyrolysis and cocombustion processes. The thermal degradation of lignocellulosic biomass and sewage sludge is a very complicated process because of a variety of reactions. Conversion of different solid biomass and sewage sludge blends to gaseous and liquid products is difficult and complicated, so TG-DTA can be helpful by interpreting the kinetics to better understand the cocombustion and copyrolysis processes. The advantage of TGA is that it can easily assess the fuel value and the temperature at which combustion, pyrolysis, and gasification start and end. It can provide information about the highest reactivity temperature, the total amount of ash remaining, and complete burning time, and these techniques are important to study the thermal behavior of the pyrolysis process. The other advantage of TG-DTA is that it can determine the purity of mineral, organic, and inorganic compounds [75]. Ergudenler et al. describe that the weight of the sample can be varied from range $1-150 \mathrm{mg}$; usually, the weight of sample greater than $10 \mathrm{mg}$ is preferred with a sensitivity of $0.01 \mathrm{mg}$. But if the excellent results are required, weight must be $1-2 \mathrm{mg}$ [143].

Table 7 describes the detailed description of the literature about the TG-DTA analysis of a different type of sample to study the pyrolysis and copyrolysis behavior under certain conditions. Mian $\mathrm{Hu}$ et al. stated that by blending sewage sludge with biomass (pine sawdust), the devolatilization properties of sewage sludge increased whereas the initial decomposition temperatures increased by increasing biomass ratio [144]. Jiang et al. stated that by increasing the ratio of biomass with sewage sludge, the reactivity of blends increases [145]. Yang et al. studied the synergistic effect of copyrolysis of sewage sludge and wheat straw. The synergistic effect resulted in speeding up the pyrolysis process, the increase in the volatiles, and reduction in char yield. The synergistic effect was maximum at a biomass proportion of $60 \%[146]$.

\subsection{Thermogravimetric Analysis of Coal/Sewage Sludge} Blends. TGA is a useful tool to examine the copyrolysis and cocombustion behavior of sewage sludge, coal, and their mixture. Different atmospheric conditions (inert condition for copyrolysis and oxidizing condition for cocombustion) can be used.

Table 8 describes the detailed description of thermal coconversion of coal and sewage sludge obtained from different sources through thermogravimetric analysis to examine the copyrolysis or cocombustion characteristics. Previous studies on the TGA of thermal coconversion of coal and dewatered sewage sludge blends show that the addition of $10 \%$ of sewage sludge in the coal-sludge blend has hardly brought any change in heat release and weight loss during thermal coconversion processes $[147,148]$. Barbosa et al. worked on the sewage sludge and coal blend impregnated with molasses to study the cocombustion characteristics and found that fuel quality obtained from this type of blend was improved [149]. But the char characteristics remained the same as that of bituminous coal. Zhuo et al. experimented on $80 \%$ coal and $20 \%$ sludge blends to study the cocombustion behavior under $\mathrm{N}_{2} / \mathrm{O}_{2}$ and $\mathrm{CO}_{2} / \mathrm{O}_{2}$ atmosphere and find out that blend gives distinctive combustion peaks as compared to combustion of sludge [150]. Jin et al. studied the influence of the blend ratio of $60 \%$ coal and $40 \%$ dewatered sewage sludge on flammability index, combustion characteristic index, and release of harmful emission and heavy metals 


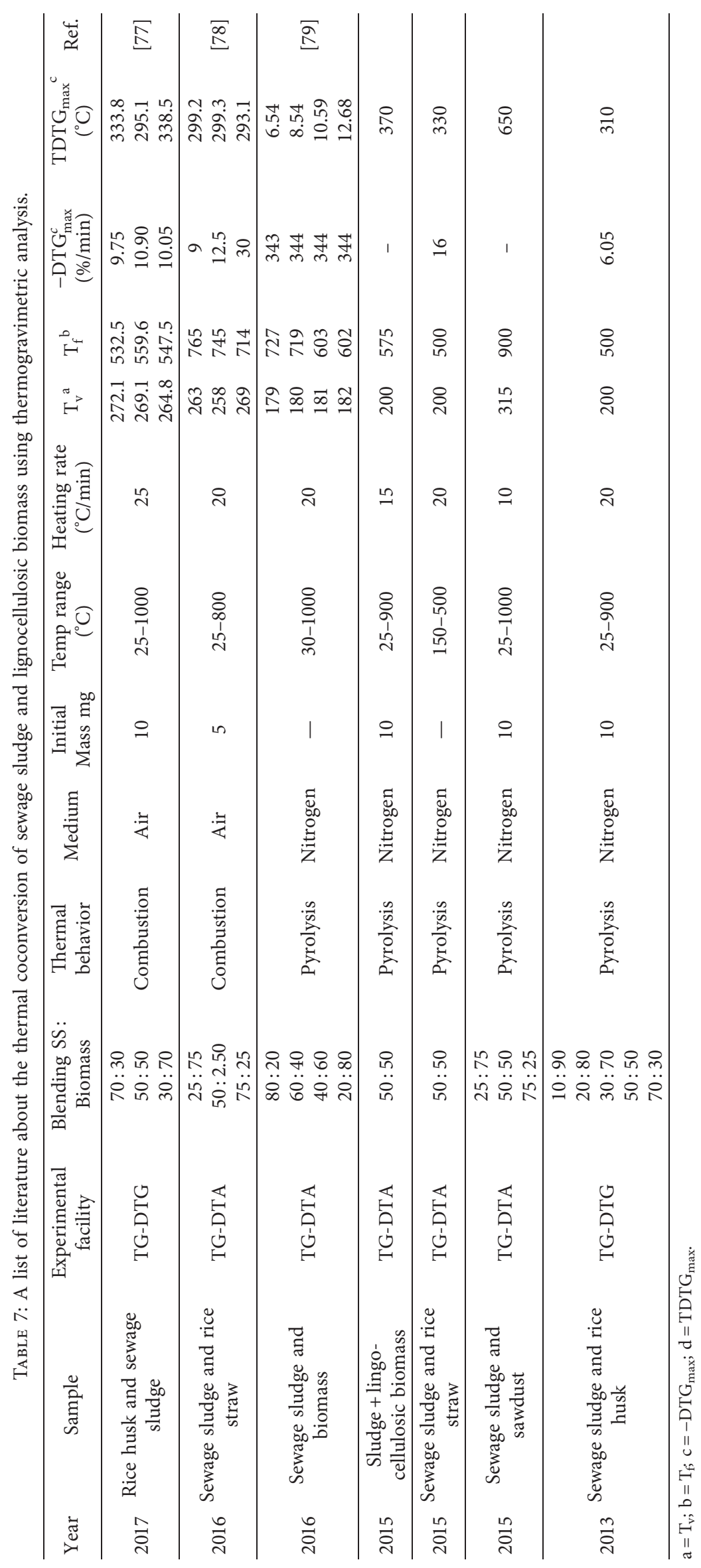




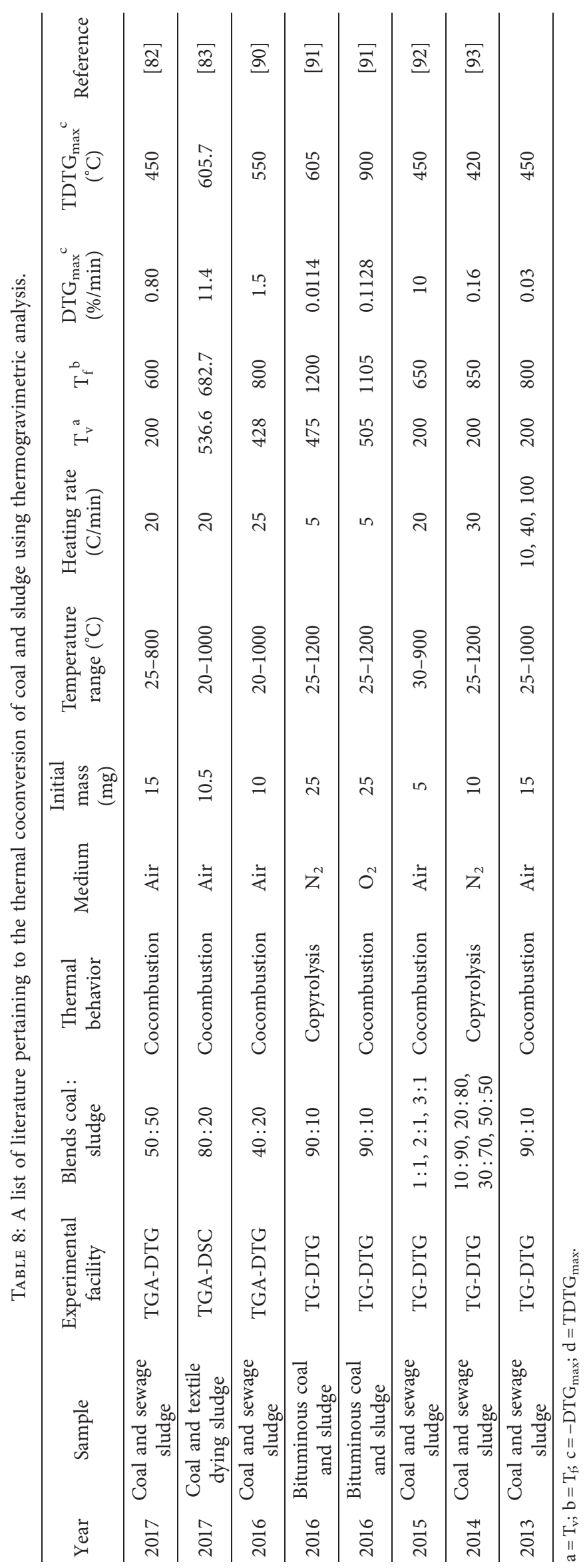


[151]. This effect is ignorable if the dewatered sewage sludge ratio is kept at less than $20 \%$. Coimbra et al. studied the copyrolysis and cocombustion behavior of bituminous coal and pulp mill sludge blend of ratio $90: 10$ and concluded that cocombustion behavior of blend is similar to that of conversion behavior of coal alone, but the copyrolysis of blends occurs at lower devolatilization temperature than that of pyrolysis of coal [52]. Zhang et al. also studied the combustion characteristics of blends of different ratios of sewage sludge and coal [53]. Xia and Li concluded from their result that the TG and DTG profiles of sewage sludge should be the same as the profile of coal but different from coal under different blending ratios [152].

\section{Future Perspectives}

This review provides a detailed description on the thermal coconversion of different biomass, sewage sludge, and coal blends through TGA to obtain optimum energy recovery entrained from a different type of sewage sludge, biomass, and coal; however, there are still many challenges to solve the problem related to the copyrolysis and cocombustion of blends. To overcome these challenges, some steps should be taken to improve the process in order to obtain maximum conversion. The production of biofuels through thermal coconversion processes is not fully established on a commercial scale, so work should be done to make it better energy recovery option commercially. The different kinetic models should be developed to find out the optimum operating condition to design the copyrolysis or cocombustion process to obtain the highest yield with lower investment. More research is required in the field of thermal coconversion of coal, biomass, and sewage sludge blends in which focus should be on scaling up and cost reduction. A computational model should be developed to optimize the physical, chemical, and reaction parameters that will help to design the process.

\section{Conclusions}

This review investigates the thermal coconversion of biomass/sewage sludge, coal/sewage sludge, and coal/biomass by using thermogravimetric analysis (TGA). Different elemental, chemical composition, and experimental conditions like the type of sample, type of reactors, different temperature ranges, heating rates, and residence time were reviewed to observe synergetic effects during copyrolysis of sewage sludge, lignocellulosic biomass, and coal blends. Many researchers have acknowledged that the copyrolysis process can expressively improve the yield and eminence of pyrolysis oil without helping aid such as catalysts, solvents, and pressure.

This technique can be considered as a simple, cheap, and effective to obtain the optimum yield. This study will provide a better understanding to reduce the failure points in obtaining and applying the copyrolysis process to obtain the maximum yield of the product. A detailed review of TGA of copyrolysis of different substances like sewage sludge, lignocellulosic biomass, and coal blends, therefore, can help plan and develop efficient industrial copyrolysis process. Based on the critical analysis, the following recommendations are suggested for future perspective:

(i) Low energy intensive operation with high-quality products techniques should be explored

(ii) Feedstock advance pretreatment processes could be adopted to enhance the devolatilization

(iii) Synergistic effect of biomass types with other residues and their interactions should be comprehensively investigated

(iv) Strict dewatering and drying steps are required before thermal coconversion processes proceeding for higher energy consumption

(v) Researcher should investigate the economic and environmental concern related to thermal coconversion processes to reduce greenhouse gases

\section{Conflicts of Interest}

The authors declare that they have no conflicts of interest.

\section{Acknowledgments}

This study was supported by Karlstad University, Sweden, and the National University of Sciences and Technology, Pakistan.

\section{References}

[1] S. R. Naqvi, I. Ali, S. Nasir et al., "Assessment of agro-industrial residues for bioenergy potential by investigating thermo-kinetic behavior in a slow pyrolysis process," Fuel, vol. 278, Article ID 118259, 2020.

[2] M. H. Tahir, Z. Zhao, J. Ren, T. Rasool, and S. R. Naqvi, "Thermo-kinetics and gaseous product analysis of banana peel pyrolysis for its bioenergy potential," Biomass and Bioenergy, vol. 122, pp. 193-201, 2019.

[3] U. Jamil, A. H. Khoja, R. Liaquat, S. R. Naqvi, W. N. N. Wan Omar, and N. A. S. Amin, "Copper and calcium-based metal organic framework (MOF) catalyst for biodiesel production from waste cooking oil: A process optimization study," Energy Conversion and Management, vol. 215, Article ID 112934, 2020.

[4] M. Shahbaz, T. Al-Ansari, M. Aslam et al., "A state of the art review on biomass processing and conversion technologies to produce hydrogen and its recovery via membrane separation," International Journal of Hydrogen Energy, vol. 45, no. 30, pp. 15166-15195, 2020.

[5] Z. Khan, S. Yusup, M. Aslam et al., "NO and $\mathrm{SO}_{2}$ emissions in palm kernel shell catalytic steam gasification with in-situ $\mathrm{CO}_{2}$ adsorption for hydrogen production in a pilot-scale fluidized bed gasification system," Journal of Cleaner Production, vol. 236, Article ID 117636, 2019.

[6] Y. Uemura, N. T. T. Tran, S. R. Naqvi, and N. Nishiyama, "Nano-catalysts for upgrading bio-oil: catalytic decarboxylation and hydrodeoxygenation," in Proceedings of the AIP Conference, AIP Publishing LLC, Bydgoszcz, Poland, 2017.

[7] Z. Hameed, Z. Aman, S. R. Naqvi, R. Tariq, I. Ali, and A. A. Makki, "Kinetic and thermodynamic analyses of sugar cane bagasse and sewage sludge co-pyrolysis process," Energy \& Fuels, vol. 32, no. 9, pp. 9551-9558, 2018. 
[8] S. R. Naqvi, Z. Hameed, R. Tariq et al., "Synergistic effect on co-pyrolysis of rice husk and sewage sludge by thermal behavior, kinetics, thermodynamic parameters and artificial neural network," Waste Management, vol. 85, pp. 131-140, 2019.

[9] S. R. Naqvi, R. Tariq, Z. Hameed et al., "Pyrolysis of high-ash sewage sludge: thermo-kinetic study using TGA and artificial neural networks," Fuel, vol. 233, pp. 529-538, 2018.

[10] M. Khan, M. T. Mehran, S. R. Naqvi et al., "Role of perovskites as a bi-functional catalyst for electrochemical water splitting: a review," International Journal of Energy Research, 2020, In press.

[11] M. Ayoub, W. J. Wei, M. Ahmad et al., "Glycerol conversion to diglycerol via etherification under microwave irradiation," In Triglycerides and Cholesterol, IntechOpen, London, UK, 2020.

[12] N. Gao, X. Jia, G. Gao, Z. Ma, C. Quan, and S. R. Naqvi, "Modeling and simulation of coupled pyrolysis and gasification of oily sludge in a rotary kiln," Fuel, vol. 279, Article ID 118152, 2020.

[13] R. M. Soncini, N. C. Means, and N. T. Weiland, "Co-pyrolysis of low rank coals and biomass: product distributions," Fuel, vol. 112, pp. 74-82, 2013.

[14] M. Rehan, A.-S. Nizami, U. Rashid, and M. R. Naqvi, "Waste biorefineries: future energy, green products and waste treatment," Frontiers in Energy Research, vol. 7, p. 55, 2019.

[15] S. R. Naqvi, R. Tariq, Z. Hameed et al., "Pyrolysis of high ash sewage sludge: kinetics and thermodynamic analysis using coats-redfern method," Renewable Energy, vol. 131, pp. 854-860, 2019.

[16] M. Balat, "Influence of coal as an energy source on environmental pollution," Energy Sources, Part A: Recovery, Utilization, and Environmental Effects, vol. 29, no. 7, pp. 581-589, 2007.

[17] I. C. I. A. J. I. e. a. Board, Insights Series, 21st Century CoalAdvanced Technology and Global Energy Solution, 2013.

[18] I. E. Agency and F. Birol, World Energy Outlook 2013, International Energy Agency, Paris, France, 2013.

[19] S. R. Naqvi, S. Jamshaid, M. Naqvi et al., "Potential of biomass for bioenergy in Pakistan based on present case and future perspectives," Renewable and Sustainable Energy Reviews, vol. 81, pp. 1247-1258, 2018.

[20] J. Yan, M. Raza Naqvi, and E. Dahlquist, "Bioenergy polygeneration, carbon capture and storage related to the pulp and paper industry and power plants," Biomass as Energy Source, pp. 163-176, CRC Press, Boca Raton, FL, USA, 2013.

[21] A. T. Ubando, W.-H. Chen, R. R. Tan, and S. R. Naqvi, "Optimal integration of a biomass-based polygeneration system in an iron production plant for negative carbon emissions," International Journal of Energy Research, 2019.

[22] M. Naqvi, J. Yan, E. Dahlquist, and S. R. Naqvi, "Waste biomass gasification based off-grid electricity generation: a case study in Pakistan," Energy Procedia, vol. 103, no. 103, pp. 406-412, 2016.

[23] M. Naqvi, J. Yan, E. Dahlquist, and S. R. Naqvi, "Off-grid electricity generation using mixed biomass compost: a scenario-based study with sensitivity analysis," Applied Energy, vol. 201, pp. 363-370, 2017.

[24] C. A. Salman, M. Naqvi, E. Thorin, and J. Yan, "Gasification process integration with existing combined heat and power plants for polygeneration of dimethyl ether or methanol: a detailed profitability analysis," Applied Energy, vol. 226, pp. 116-128, 2018.
[25] S. Niu, M. Chen, Y. Li, and T. Lu, "Combustion characteristics of municipal sewage sludge with different initial moisture contents," Journal of Thermal Analysis and Calorimetry, vol. 129, no. 2, pp. 1189-1199, 2017.

[26] S. R. Naqvi and M. Naqvi, "Catalytic fast pyrolysis of rice husk: influence of commercial and synthesized microporous zeolites on deoxygenation of biomass pyrolysis vapors," International Journal of Energy Research, vol. 42, no. 3, pp. 1352-1362, 2018.

[27] U. Sikander, M. F. Samsudin, S. Sufian et al., "Tailored hydrotalcite-based $\mathrm{Mg}-\mathrm{Ni}-\mathrm{Al}$ catalyst for hydrogen production via methane decomposition: effect of nickel concentration and spinel-like structures," International Journal of Hydrogen Energy, vol. 44, no. 28, pp. 14424-14433, 2019.

[28] F. Abnisa, W. M. A. Wan Daud, and Management, "A review on co-pyrolysis of biomass: an optional technique to obtain a high-grade pyrolysis oil," Energy Conversion and Management, vol. 87, pp. 71-85, 2014.

[29] J. Alvarez, M. Amutio, G. Lopez, J. Bilbao, and M. Olazar, "Fast co-pyrolysis of sewage sludge and lignocellulosic biomass in a conical spouted bed reactor," Fuel, vol. 159, pp. 810-818, 2015.

[30] S. Malik, F. Fatima, A. Imran et al., "Improved project control for sustainable development of construction sector to reduce environment risks," Journal of Cleaner Production, vol. 240, Article ID 118214, 2019.

[31] M. Bassyouni, I. Ali, and S. M. S. Abdel-hamid, "Study of thermo-kinetic properties of graphite micro-plateletenriched vinyl ester composites," Journal of Thermal Analysis and Calorimetry, vol. 131, no. 2, pp. 1055-1065, 2018.

[32] K.-M. Lu, W.-J. Lee, W.-H. Chen, and T.-C. Lin, "Thermogravimetric analysis and kinetics of co-pyrolysis of raw/ torrefied wood and coal blends," Applied Energy, vol. 105, pp. 57-65, 2013.

[33] I. Ali, "Misuse of pre-exponential factor in the kinetic and thermodynamic studies using thermogravimetric analysis and its implications," Bioresource Technology Reports, vol. 2, pp. 88-91, 2018.

[34] M. H. Tahir, G. Çakman, J. L. Goldfarb, Y. Topcu, S. R. Naqvi, and S. Ceylan, "Demonstrating the suitability of canola residue biomass to biofuel conversion via pyrolysis through reaction kinetics, thermodynamics and evolved gas analyses," Bioresource Technology, vol. 279, pp. 67-73, 2019.

[35] A. Magdziarz and M. Wilk, "Thermogravimetric study of biomass, sewage sludge and coal combustion," Energy Conversion and Management, vol. 75, pp. 425-430, 2013.

[36] A. Inayat, M. Ayoub, A. Z. Abdullah, S. Ullah, and S. R. Naqvi, "Decomposition of $\mathrm{N}_{2} \mathrm{O}$ at low temperature over $\mathrm{CO}_{3} \mathrm{O}_{4}$ prepared by different methods," Environmental Progress \& Sustainable Energy, vol. 38, no. 4, p. 13129, 2019.

[37] Z. Gogebakan, Y. Gogebakan, and N. Selçuk, "Co-firing of olive residue with lignite in bubbling FBC," Combustion Science and Technology, vol. 180, no. 5, pp. 854-868, 2008.

[38] A. Bokhari, L. F. Chuah, L. Z. Y. Michelle et al., "Microwave enhanced catalytic conversion of canola-based methyl ester: optimization and parametric study," in Advanced Biofuels, pp. 153-166, Elsevier, Amsterdam, Netherlands, 2019.

[39] M. Naqvi, E. Dahlquist, A.-S. Nizami et al., "Gasification integrated with small chemical pulp mills for fuel and energy production," Energy Procedia, vol. 142, pp. 977-983, 2017.

[40] N. Hossain, J. H. Zaini, and T. J. I. J. o. T. Mahlia, "A review of bioethanol production from plant-based waste biomass by yeast fermentation," International Journal of Technology, vol. 8, no. 1, p. 5, 2017. 
[41] N. Hossain, J. Zaini, and T. M. I. Mahlia, "Experimental investigation of energy properties forStigonematalessp. microalgae as potential biofuel feedstock," International Journal of Sustainable Engineering, vol. 12, no. 2, pp.123-130, 2019.

[42] N. Hossain and T. M. I. Mahlia, "Progress in physicochemical parameters of microalgae cultivation for biofuel production," Critical Reviews in Biotechnology, vol. 39, no. 6, pp. 835-859, 2019.

[43] S. R. Naqvi, Y. Uemura, N. B. Osman, S. Yusup, and M. F. Nuruddin, "Physiochemical properties of pyrolysis oil derived from fast pyrolysis of wet and dried rice husk in a free fall reactor," in Applied Mechanics and Materials, Trans Tech Publications, Stafa-Zurich, Switzerland, 2014.

[44] A. Christodoulou and K. Stamatelatou, "Overview of legislation on sewage sludge management in developed countries worldwide," Water Science and Technology, vol. 73, no. 3, pp. 453-462, 2015.

[45] D. Fytili and A. Zabaniotou, "Utilization of sewage sludge in EU application of old and new methods-a review," Renewable and Sustainable Energy Reviews, vol. 12, no. 1, pp. 116-140, 2008.

[46] M. Buyukada, "Uncertainty estimation by Bayesian approach in thermochemical conversion of walnut hull and lignite coal blends," Bioresource Technology, vol. 232, pp. 87-92, 2017.

[47] L. Zhang, S. Xu, W. Zhao, and S. Liu, "Co-pyrolysis of biomass and coal in a free fall reactor," Fuel, vol. 86, no. 3, pp. 353-359, 2007.

[48] Y. G. Pan, E. Velo, X. Roca, J. J. Manyà, and L. Puigjaner, "Fluidized-bed co-gasification of residual biomass/poor coal blends for fuel gas production," Fuel, vol. 79, no. 11, pp. 1317-1326, 2000.

[49] M. P. Aznar, M. A. Caballero, J. A. Sancho, and E. Francés, "Plastic waste elimination by co-gasification with coal and biomass in fluidized bed with air in pilot plant," Fuel Processing Technology, vol. 87, no. 5, pp. 409-420, 2006.

[50] K. Kumabe, T. Hanaoka, S. Fujimoto, T. Minowa, and K. Sakanishi, "Co-gasification of woody biomass and coal with air and steam," Fuel, vol. 86, no. 5-6, pp. 684-689, 2007.

[51] H. N. S. Schafer, "Carboxyl groups and ion exchange in lowrank coals," Fuel, vol. 49, no. 2, pp. 197-213, 1970.

[52] R. N. Coimbra, S. Paniagua, C. Escapa, L. F. Calvo, and M. Otero, "Thermal valorization of pulp mill sludge by coprocessing with coal," Waste and Biomass Valorization, vol. 7, no. 4, pp. 995-1006, 2016.

[53] L. Zhang, F. Duan, and Y. Huang, "Effect of organic calcium compounds on combustion characteristics of rice husk, sewage sludge, and bituminous coal: thermogravimetric investigation," Bioresource Technology, vol. 181, pp. 62-71, 2015.

[54] G. K. Parshetti, A. Quek, R. Betha, and R. Balasubramanian, "TGA-FTIR investigation of co-combustion characteristics of blends of hydrothermally carbonized oil palm biomass (EFB) and coal," Fuel Processing Technology, vol. 118, pp. 228-234, 2014.

[55] J. Q. Xia and H. P. Li, "Co-pyrolysis charateristics study of dianchi lake sludge and coal," Advanced Materials Research, vol. 860-863, pp. 518-521, 2014.

[56] D.-X. Li, J.-B. Liu, M. R. Farahani, M. Imran, and M. K. Jamil, "Techno-economic study of coal pyrolysis for production of chemicals using a high-pressure fluidized bed," Energy Sources, Part B: Economics, Planning, and Policy, vol. 12, no. 7, pp. 654-658, 2017.
[57] K. Jayaraman, M. V. Kok, and I. Gokalp, "Thermogravimetric and mass spectrometric (TG-MS) analysis and kinetics of coal-biomass blends," Renewable Energy, vol. 101, pp. 293-300, 2017.

[58] Z. Wu, W. Yang, H. Meng et al., "Physicochemical structure and gasification reactivity of co-pyrolysis char from two kinds of coal blended with lignocellulosic biomass: effects of the carboxymethylcellulose sodium," Applied Energy, vol. 207, pp. 96-106, 2017.

[59] S. Zellagui, C. Schönnenbeck, N. Zouaoui-Mahzoul et al., "Pyrolysis of coal and woody biomass under $\mathrm{N}_{2}$ and $\mathrm{CO}_{2}$ atmospheres using a drop tube furnace-experimental study and kinetic modeling," Fuel Processing Technology, vol. 148, pp. 99-109, 2016.

[60] Z. Wu, S. Wang, J. Zhao, L. Chen, and H. Meng, "Synergistic effect on thermal behavior during co-pyrolysis of lignocellulosic biomass model components blend with bituminous coal,” Bioresource Technology, vol. 169, pp. 220-228, 2014.

[61] Y. Zhang and Y. Zheng, "Co-gasification of coal and biomass in a fixed bed reactor with separate and mixed bed configurations," Fuel, vol. 183, pp. 132-138, 2016.

[62] M. Rahman, A. Samanta, and R. Gupta, "Production and characterization of ash-free coal from low-rank Canadian coal by solvent extraction," Fuel Processing Technology, vol. 115, pp. 88-98, 2013.

[63] M. S. Bhatt, "Effect of ash in coal on the performance of coal fired thermal power plants. Part I: primary energy effects," Energy Sources, Part A: Recovery, Utilization, and Environmental Effects, vol. 28, no. 1, pp. 25-41, 2006.

[64] B.-J. Lin, W.-H. Chen, T.-H. Hsieh, H. C. Ong, P. L. Show, and S. R. Naqvi, "Oxidative reaction interaction and synergistic index of emulsified pyrolysis bio-oil/diesel fuels," Renewable Energy, vol. 136, pp. 223-234, 2019.

[65] S. R. Naqvi, Y. Uemura, N. Osman, and S. Yusup, "Production and evaluation of physicochemical characteristics of paddy husk bio-char for its C sequestration applications," BioEnergy Research, vol. 8, no. 4, pp. 1800-1809, 2015.

[66] Z. Wu, Y. Li, D. Xu, and H. Meng, "Co-pyrolysis of lignocellulosic biomass with low-quality coal: optimal design and synergistic effect from gaseous products distribution," Fuel, vol. 236, pp. 43-54, 2019.

[67] M. Naqvi, E. Dahlquist, and J. Yan, "Complementing existing CHP plants using biomass for production of hydrogen and burning the residual gas in a CHP boiler," Biofuels, vol. 8 , no. 6, pp. 675-683, 2017.

[68] A. S. Qureshi, I. Khushk, S. R. Naqvi et al., "Fruit waste to energy through open fermentation," Energy Procedia, vol. 142, pp. 904-909, 2017.

[69] Q. Sohaib, A. Muhammad, and M. Younas, "Fast pyrolysis of sugarcane bagasse: effect of pyrolysis conditions on final product distribution and properties," Energy Sources, Part A: Recovery, Utilization, and Environmental Effects, vol. 39, no. 2, pp. 184-190, 2017.

[70] S. Al Arni, "Comparison of slow and fast pyrolysis for converting biomass into fuel," Renewable Energy, vol. 124, pp. 197-201, 2018.

[71] F. Pinto, J. Gominho, R. N. André et al., "Effect of rice husk torrefaction on syngas production and quality," Energy \& Fuels, vol. 31, no. 5, pp. 5183-5192, 2017.

[72] A. K. Varma and P. Mondal, "Physicochemical characterization and pyrolysis kinetic study of sugarcane bagasse using thermogravimetric analysis," Journal of Energy Resources Technology, vol. 138, no. 5, 2016. 
[73] S. Yi, X.-m. He, H.-t. Lin, H. Zheng, C.-h. Li, and C. Li, "Synergistic effect in low temperature co-pyrolysis of sugarcane bagasse and lignite," Korean Journal of Chemical Engineering, vol. 33, no. 10, pp. 2923-2929, 2016.

[74] Y. Yu, Y. Yang, Z. Cheng et al., "Pyrolysis of rice husk and corn stalk in auger reactor. 1. Characterization of char and gas at various temperatures," Energy \& Fuels, vol. 30, no. 12, pp. 10568-10574, 2016.

[75] J. I. Montoya, C. Valdés, F. Chejne et al., "Bio-oil production from Colombian bagasse by fast pyrolysis in a fluidized bed: an experimental study," Journal of Analytical and Applied Pyrolysis, vol. 112, pp. 379-387, 2015.

[76] S. A. El-Sayed and M. E. Mostafa, "Pyrolysis characteristics and kinetic parameters determination of biomass fuel powders by differential thermal gravimetric analysis (TGA/ DTG)," Energy Conversion and Management, vol. 85, pp. 165-172, 2014.

[77] T. Kan and Q. Li, "Influence of temperature on properties of products from steam pyrolysis of rice husk in a fluidized bed," Energy Sources, Part A: Recovery, Utilization, and Environmental Effects, vol. 37, no. 17, pp. 1883-1889, 2015.

[78] S. Vecino Mantilla, P. Gauthier-Maradei, P. Álvarez Gil, and S. Tarazona Cárdenas, "Comparative study of bio-oil production from sugarcane bagasse and palm empty fruit bunch: yield optimization and bio-oil characterization," Journal of Analytical and Applied Pyrolysis, vol. 108, pp. 284-294, 2014.

[79] M. S. Abu Bakar and J. O. Titiloye, "Catalytic pyrolysis of rice husk for bio-oil production," Journal of Analytical and Applied Pyrolysis, vol. 103, pp. 362-368, 2013.

[80] S. Gu, J. Zhou, Z. Luo, Q. Wang, and M. Ni, "A detailed study of the effects of pyrolysis temperature and feedstock particle size on the preparation of nanosilica from rice husk," Industrial Crops and Products, vol. 50, pp. 540-549, 2013.

[81] D. Özçimen and A. Ersoy-Meriçboyu, "Characterization of biochar and bio-oil samples obtained from carbonization of various biomass materials," Renewable Energy, vol. 35, no. 6, pp. 1319-1324, 2010.

[82] N. Hossain and N. A. H. Morni, "Co-pelletization of microalgae-sewage sludge blend with sub-bituminous coal as solid fuel feedstock," BioEnergy Research, vol. 13, no. 2, pp. 618-629, 2020.

[83] B. Yousaf, G. Liu, Q. Abbas et al., "Systematic investigation on combustion characteristics and emission-reduction mechanism of potentially toxic elements in biomass- and biochar-coal co-combustion systems," Applied Energy, vol. 208, pp. 142-157, 2017.

[84] N. Ruiz-Gómez, V. Quispe, J. Ábrego, M. Atienza-Martínez, M. B. Murillo, and G. Gea, "Co-pyrolysis of sewage sludge and manure," Waste Management, vol. 59, pp. 211-221, 2017.

[85] H. Chen, Y. Zhai, B. Xu et al., "Characterization of bio-oil and biochar from high-temperature pyrolysis of sewage sludge," Environmental Technology, vol. 36, no. 4, pp. 470478, 2015.

[86] P. Manara and A. Zabaniotou, "Towards sewage sludge based biofuels via thermochemical conversion-a review," Renewable and Sustainable Energy Reviews, vol. 16, no. 5, pp. 2566-2582, 2012.

[87] I. Fonts, G. Gea, M. Azuara, J. Ábrego, and J. Arauzo, "Sewage sludge pyrolysis for liquid production: a review," Renewable and Sustainable Energy Reviews, vol. 16, no. 5, pp. 2781-2805, 2012.

[88] M. C. Samolada and A. A. Zabaniotou, "Comparative assessment of municipal sewage sludge incineration, gasification and pyrolysis for a sustainable sludge-to-energy management in Greece," Waste Management, vol. 34, no. 2, pp. 411-420, 2014.

[89] M. Inguanzo, A. Domínguez, J. A. Menéndez, C. G. Blanco, and J. J. Pis, "On the pyrolysis of sewage sludge: the influence of pyrolysis conditions on solid, liquid and gas fractions," Journal of Analytical and Applied Pyrolysis, vol. 63, no. 1, pp. 209-222, 2002.

[90] K. Wang, Y. Zheng, X. Zhu, C. E. Brewer, and R. C. Brown, "Ex-situ catalytic pyrolysis of wastewater sewage sludge-a micro-pyrolysis study," Bioresource Technology, vol. 232, pp. 229-234, 2017.

[91] J. Alvarez, G. Lopez, M. Amutio et al., "Characterization of the bio-oil obtained by fast pyrolysis of sewage sludge in a conical spouted bed reactor," Fuel Processing Technology, vol. 149, pp. 169-175, 2016.

[92] H. Fan and K. He, "Fast pyrolysis of sewage sludge in a curiepoint pyrolyzer: the case of sludge in the city of shanghai, China," Energy \& Fuels, vol. 30, no. 2, pp. 1020-1026, 2016.

[93] Y.-F. Huang, C.-H. Shih, P.-T. Chiueh, and S.-L. Lo, "Microwave co-pyrolysis of sewage sludge and rice straw," Energy, vol. 87, pp. 638-644, 2015.

[94] J. Alvarez, M. Amutio, G. Lopez, I. Barbarias, J. Bilbao, and M. Olazar, "Sewage sludge valorization by flash pyrolysis in a conical spouted bed reactor," Chemical Engineering Journal, vol. 273, pp. 173-183, 2015.

[95] Q. Xie, P. Peng, S. Liu et al., "Fast microwave-assisted catalytic pyrolysis of sewage sludge for bio-oil production," Bioresource Technology, vol. 172, pp. 162-168, 2014

[96] Q. Zhang, M. Luo, L. Yan, A. Yang, and X. Hui, "Kinetic analysis of low-rank coal pyrolysis by model-free and modelfitting methods," Journal of Chemistry, vol. 2019, Article ID 9075862, 7 pages, 2019

[97] X. Wen, Y. Bai, S. Zhang, A. Ding, L. Zheng, and J. Li, "Distributions and sources of sedimentary sterols as well as their indications of sewage contamination in the Guanting reservoir, Beijing," Journal of Chemistry, vol. 2020, Article ID 3050687, 11 pages, 2020.

[98] X. Xu, B. Zhao, M. Sun et al., "Co-pyrolysis characteristics of municipal sewage sludge and hazelnut shell by TG-DTG-MS and residue analysis," Waste Management, vol. 62, pp. 91100, 2017.

[99] S. Xiong, J. Zhuo, B. Zhang, and Q. Yao, "Effect of moisture content on the characterization of products from the pyrolysis of sewage sludge," Journal of Analytical and Applied Pyrolysis, vol. 104, pp. 632-639, 2013.

[100] J.-P. Cao, L.-Y. Li, K. Morishita et al., "Nitrogen transformations during fast pyrolysis of sewage sludge," Fuel, vol. 104, pp. 1-6, 2013.

[101] S. Deng, H. Tan, X. Wang et al., "Investigation on the fast copyrolysis of sewage sludge with biomass and the combustion reactivity of residual char," Bioresource Technology, vol. 239, pp. 302-310, 2017.

[102] B. Zhang, Z. Zhong, M. Min, K. Ding, Q. Xie, and R. Ruan, "Catalytic fast co-pyrolysis of biomass and food waste to produce aromatics: analytical Py-GC/MS study," Bioresource Technology, vol. 189, pp. 30-35, 2015.

[103] A. V. Bridgwater, "Review of fast pyrolysis of biomass and product upgrading," Biomass and Bioenergy, vol. 38, pp. 68-94, 2012.

[104] I. Velghe, R. Carleer, J. Yperman, and S. Schreurs, "Study of the pyrolysis of municipal solid waste for the production of valuable products," Journal of Analytical and Applied Pyrolysis, vol. 92, no. 2, pp. 366-375, 2011. 
[105] Y. G. Pan, E. Velo, and L. Puigjaner, "Pyrolysis of blends of biomass with poor coals," Fuel, vol. 75, no. 4, pp. 412-418, 1996.

[106] S. R. Naqvi, Y. Uemura, and S. B. Yusup, "Catalytic pyrolysis of paddy husk in a drop type pyrolyzer for bio-oil production: the role of temperature and catalyst," Journal of Analytical and Applied Pyrolysis, vol. 106, pp. 57-62, 2014.

[107] F. Guo, X. Li, Y. Wang, Y. Liu, T. Li, and C. Guo, "Characterization of Zhundong lignite and biomass co-pyrolysis in a thermogravimetric analyzer and a fixed bed reactor," Energy, vol. 141, pp. 2154-2163, 2017.

[108] Z. Wang, K. Liu, L. Xie, H. Zhu, S. Ji, and X. Shu, "Effects of residence time on characteristics of biochars prepared via copyrolysis of sewage sludge and cotton stalks," Journal of Analytical and Applied Pyrolysis, vol. 142, Article ID 104659, 2019.

[109] T. Nussbaumer, "Combustion and Co-combustion of biomass: fundamentals, technologies, and primary measures for emission reduction," Energy \& Fuels, vol. 17, no. 6, pp. 1510-1521, 2003.

[110] J. Zuwała and J. Lasek, "6-Co-combustion of low-rank coals with biomass," in Low-Rank Coals for Power Generation, Fuel and Chemical Production, Z. Luo and M. Agraniotis, Eds., pp. 125-158, Woodhead Publishing, Sawston, UK, 2017.

[111] H.-m. Xiao, X.-q. Ma, and Z.-y. Lai, "Isoconversional kinetic analysis of co-combustion of sewage sludge with straw and coal," Applied Energy, vol. 86, no. 9, pp. 1741-1745, 2009.

[112] S. Munir, W. Nimmo, and B. M. Gibbs, "The effect of air staged, co-combustion of pulverised coal and biomass blends on NOx emissions and combustion efficiency," Fuel, vol. 90, no. 1, pp. 126-135, 2011.

[113] C. Brage, Q. Yu, G. Chen, and K. Sjöström, “Tar evolution profiles obtained from gasification of biomass and coal," Biomass and Bioenergy, vol. 18, no. 1, pp. 87-91, 2000.

[114] I. Narváez, J. Corella, and A. Orío, "Fresh tar (from a biomass gasifier) elimination over a commercial steam-reforming catalyst. Kinetics and effect of different variables of operation," Industrial \& Engineering Chemistry Research, vol. 36, no. 2, pp. 317-327, 1997.

[115] F. Pinto, H. Lopes, R. N. André, I. Gulyurtlu, and I. Cabrita, "Effect of catalysts in the quality of syngas and by-products obtained by co-gasification of coal and wastes. (1) Tars and nitrogen compounds abatement," Fuel, vol. 86, no. 14, pp. 2052-2063, 2007.

[116] F. Paradela, F. Pinto, I. Gulyurtlu, I. Cabrita, and N. Lapa, "Study of the co-pyrolysis of biomass and plastic wastes," Clean Technologies and Environmental Policy, vol. 11, no. 1, pp. 115-122, 2009.

[117] A.-G. Collot, Y. Zhuo, D. R. Dugwell, and R. Kandiyoti, "Copyrolysis and co-gasification of coal and biomass in benchscale fixed-bed and fluidised bed reactors," Fuel, vol. 78, no. 6, pp. 667-679, 1999.

[118] R. N. André, "Fluidised bed co-gasification of coal and olive oil industry wastes," Fuel, vol. 84, no. 12, pp. 1635-1644, 2005.

[119] Y. Zheng, P. A. Jensen, A. D. Jensen, B. Sander, and H. Junker, "Ash transformation during co-firing coal and straw,” Fuel, vol. 86, no. 7-8, pp. 1008-1020, 2007.

[120] M. Strand, M. Bohgard, E. Swietlicki, A. Gharibi, and M. Sanati, "Laboratory and field test of a sampling method for characterization of combustion aerosols at high temperatures," Aerosol Science and Technology, vol. 38, no. 8, pp. 757-765, 2004.
[121] H. Wu, T. Wall, G. Liu, and G. Bryant, "Ash liberation from included minerals during combustion of pulverized coal: the relationship with char structure and burnout," Energy \& Fuels, vol. 13, no. 6, pp. 1197-1202, 1999.

[122] M. Bernardo, N. Lapa, M. Gonçalves et al., "Physicochemical properties of chars obtained in the co-pyrolysis of waste mixtures," Journal of Hazardous Materials, vol. 219220, pp. 196-202, 2012.

[123] M. Brebu, S. Ucar, C. Vasile, and J. Yanik, "Co-pyrolysis of pine cone with synthetic polymers," Fuel, vol. 89, no. 8, pp. 1911-1918, 2010.

[124] Y. Betancur, A. Sánchez, A. Bueno-López, and D. López, "Impact of biomass and main biomass components on coal reactivity under oxy-combustion conditions-A comparison of physicochemical char properties obtained under $\mathrm{N}_{2}$ and $\mathrm{CO}_{2}$ atmospheres," Energy \& Fuels, vol. 31, no. 5, pp. 5603-5611, 2017.

[125] G. Wang, J. Zhang, J. Shao et al., "Thermal behavior and kinetic analysis of co-combustion of waste biomass/low rank coal blends," Energy Conversion and Management, vol. 124, pp. 414-426, 2016.

[126] J. Zhu, L. Wan, H. Chen, Y. Zhu, and L. Yang, "Pilot test of Co-pyrolysis characteristics of wet sewage sludge and sawdust in an external heating moving bed," Energy Procedia, vol. 105, pp. 570-575, 2017.

[127] S. Li, X. Chen, A. Liu, L. Wang, and G. Yu, "Co-pyrolysis characteristic of biomass and bituminous coal," Bioresource Technology, vol. 179, pp. 414-420, 2015.

[128] F. Pinto, M. Miranda, and P. Costa, "Production of liquid hydrocarbons from rice crop wastes mixtures by co-pyrolysis and co-hydropyrolysis," Fuel, vol. 174, pp. 153-163, 2016.

[129] W. Zhang, C. Yuan, J. Xu, and X. Yang, "Beneficial synergetic effect on gas production during co-pyrolysis of sewage sludge and biomass in a vacuum reactor," Bioresource Technology, vol. 183, pp. 255-258, 2015.

[130] L. M. Torquato, C. E. M. Braz, C. A. Ribeiro, J. M. V. Capela, and M. S. Crespi, "Kinetic study of the co-firing of bagassesludge blends," Journal of Thermal Analysis and Calorimetry, vol. 121, no. 1, pp. 499-507, 2015.

[131] H.-S. Ding and H. Jiang, "Self-heating co-pyrolysis of excessive activated sludge with waste biomass: energy balance and sludge reduction," Bioresource Technology, vol. 133, pp. 16-22, 2013.

[132] S. R. Naqvi, Y. Uemura, N. Osman, and S. Yusup, "Kinetic study of the catalytic pyrolysis of paddy husk by use of thermogravimetric data and the coats-redfern model," Research on Chemical Intermediates, vol. 41, no. 12, pp. 9743-9755, 2015.

[133] M. Sami, K. Annamalai, and M. Wooldridge, "Co-firing of coal and biomass fuel blends," Progress in Energy and Combustion Science, vol. 27, no. 2, pp. 171-214, 2001.

[134] C. A. Strydom, T. Z. Sehume, J. R. Bunt, and J. C. van Dyk, "The influence of selected biomass additions on the co-pyrolysis with an inertinite-rich medium rank $\mathrm{C}$ grade South African coal," Journal of the Southern African Institute of Mining and Metallurgy, vol. 115, no. 8, pp. 707-716, 2015.

[135] C. Xu, S. Hu, J. Xiang et al., "Interaction and kinetic analysis for coal and biomass co-gasification by TG-FTIR," Bioresource Technology, vol. 154, pp. 313-321, 2014.

[136] A. O. Aboyade, J. F. Görgens, M. Carrier, E. L. Meyer, and J. H. Knoetze, "Thermogravimetric study of the pyrolysis characteristics and kinetics of coal blends with corn and sugarcane residues," Fuel Processing Technology, vol. 106, pp. 310-320, 2013. 
[137] D. K. Park, S. D. Kim, S. H. Lee, and J. G. Lee, "Co-pyrolysis characteristics of sawdust and coal blend in TGA and a fixed bed reactor," Bioresource Technology, vol. 101, no. 15, pp. 6151-6156, 2010.

[138] D. A. Mortari, I. Ávila, and P. M. Crnkovic, "Co-firing study of sugar cane bagasse and coal applying thermogravimetric analysis and kinetic," in Proceedings of the International Congress of Mechanical Engineering-COBEM, Ribeirão Preto, Brazil, 2013.

[139] S. Werle and R. K. Wilk, "A review of methods for the thermal utilization of sewage sludge: the polish perspective," Renewable Energy, vol. 35, no. 9, pp. 1914-1919, 2010.

[140] J. Kalembkiewicz and U. Chmielarz, "Ashes from co-combustion of coal and biomass: new industrial wastes," Resources, Conservation and Recycling, vol. 69, pp. 109-121, 2012.

[141] S. R. Naqvi, A. Bibi, M. Naqvi et al., "New trends in improving gasoline quality and octane through naphtha isomerization: a short review," Applied Petrochemical Research, vol. 8, no. 3, pp. 131-139, 2018.

[142] S. R. Naqvi, Y. Uemura, S. Yusup, N. Nishiyama, and M. Naqvi, "Catalytic consequences of micropore topology on biomass pyrolysis vapors over shape selective zeolites," Energy Procedia, vol. 105, pp. 557-561, 2017.

[143] A. Ergudenler and A. E. Ghaly, "Determination of reaction kinetics of wheat straw using thermogravimetric analysis," Applied Biochemistry and Biotechnology, vol. 34-35, no. 1, pp. 75-91, 1992.

[144] H. Rong, T. Wang, M. Zhou, H. Wang, H. Hou, and Y. Xue, "Combustion characteristics and slagging during co-combustion of rice husk and sewage sludge blends," Energies, vol. 10, no. 4, 2017.

[145] L.-b. Jiang, X.-z. Yuan, H. Li et al., "Co-pelletization of sewage sludge and biomass: thermogravimetric analysis and ash deposits," Fuel Processing Technology, vol. 145, pp. 109115, 2016.

[146] X. Wang, S. Deng, H. Tan et al., "Synergetic effect of sewage sludge and biomass co-pyrolysis: a combined study in thermogravimetric analyzer and a fixed bed reactor," Energy Conversion and Management, vol. 118, pp. 399-405, 2016.

[147] M. Otero, L. Calvo, M. Gil, A. Garcia, and A. Moran, "Cocombustion of different sewage sludge and coal: a nonisothermal thermogravimetric kinetic analysis," Bioresource Technology, vol. 99, no. 14, pp. 6311-6319, 2008.

[148] S.-W. Park and C.-H. Jang, "Characteristics of carbonized sludge for co-combustion in pulverized coal power plants," Waste Management, vol. 31, no. 3, pp. 523-529, 2011.

[149] R. Barbosa, N. Lapa, D. Boavida, H. Lopes, I. Gulyurtlu, and B. Mendes, "Co-combustion of coal and sewage sludge: chemical and ecotoxicological properties of ashes," Journal of Hazardous Materials, vol. 170, no. 2-3, pp. 902-909, 2009.

[150] Z. Zhuo, J. Liu, S. Sun et al., "Thermogravimetric characteristics of textile dyeing sludge, coal and their blend in $\mathrm{N}_{2}$ / $\mathrm{O}_{2}$ and $\mathrm{CO}_{2} / \mathrm{O}_{2}$ atmospheres," Applied Thermal Engineering, vol. 111, pp. 87-94, 2017.

[151] Y. Jin, Y. Li, and F. Liu, "Combustion effects and emission characteristics of $\mathrm{SO}_{2}, \mathrm{CO}, \mathrm{NOx}$ and heavy metals during cocombustion of coal and dewatered sludge," Frontiers of Environmental Science \& Engineering, vol. 10, no. 1, pp. 201-210, 2016.

[152] J. Q. Xia and H. P. Li, "Co-pyrolysis charateristics study of Dianchi lake sludge and coal," in Advanced Materials Research, Trans Tech Publications, Stafa-Zurich, Switzerland, 2014. 